\title{
Late Neoarchaean-Palaeoproterozoic supracrustal basin-fills of the Kaapvaal craton: relevance of the supercontinent cycle, the "Great Oxidation Event" and "Snowball Earth"?
}

\author{
P.G. Eriksson ${ }^{\mathrm{a}}$, N. Lenhardt ${ }^{\mathrm{a}}$, D.T. Wright ${ }^{\mathrm{b}}$, R. Mazumder ${ }^{\mathrm{c}}$ and A.J. Bumby ${ }^{\mathrm{a}}$ \\ ${ }^{a}$ Department of Geology, University of Pretoria, Pretoria 0002, South Africa \\ ${ }^{b}$ Department of Geology, University of Leicester, University Road, Leicester LE1 7RH \\ ${ }^{c}$ Geological Studies Unit and Fluvial Mechanics Laboratory, Indian Statistical Institute, \\ 203 B.T. Road, Kolkata 700 108, India
}

\begin{abstract}
The application of the onset of supercontinentality, the "Great Oxidation Event" (GOE) and the first global-scale glaciation in the Neoarchaean-Palaeoproterozoic as panacea-like events providing a framework or even chronological piercing points in Earth's history at this time, is questioned. There is no solid evidence that the Kaapvaal craton was part of a larger amalgamation at this time, and its glacigenic record is dominated by deposits supporting the operation of an active hydrological cycle in parallel with glaciation, thereby arguing against the "Snowball Earth Hypothesis". While the Palaeoproterozoic geological record of Kaapvaal does broadly support the GOE, this postulate itself is being questioned on the basis of isotopic data used as oxygen-proxies, and sedimentological data from extant river systems on the craton argue for a prolongation of the greenhouse palaeo-atmosphere (possibly in parallel with a relative elevation of oxygen levels) which presumably preceded the GOE. The possibility that these widespread events may have been diachronous at the global scale is debated.
\end{abstract}

Keywords: Neoarchaean-Palaeoproterozoic; Kaapvaal craton; sedimentary record; supercontinentality, ca. 2.3 Ga oxidation event, global glaciation

\section{Introduction}

Established literature over several decades has resulted in a relatively uniform view of Neoarchaean-Palaeoproterozoic global geological evolution becoming well entrenched within the minds of possibly a majority of researchers (e.g., Fig. 1). An early (possibly the earliest) supercontinent in the Neoarchaean ("Kenorland") is thought to have undergone protracted breakup from about 2.45 to 2.1 Ga followed by dispersal of daughter fragments by $\sim 2.0 \mathrm{Ga}$ (e.g., Aspler and Chiarenzelli, 1998). The latter authors argued for a poorly constrained "southern" (modern framework) supercontinent as well, and many others have supported a specific "Vaalbara" (cf. also expanded "Zimvaalbara" to include the Zimbabwe craton) (Cheney, 1996) amalgamation of the Pilbara and Kaapvaal cratons (e.g., De Kock et al., 2009 for a recent example). As a result, the specific Kenorland example where reasonably solid geological data supports an amalgamation of cratonic blocks of North America, and the Baltic and possibly Siberian shields, has become broadened into a broader globally applicable concept of universal supercontinentality at the end of the Archaean. Insightful comment on the late Archaean supercontinental record is provided by Bleeker (2003), who also argues against an 
idealized view of a single Neoarchaean supercontinent (cf. Kenorland); instead, he proposes several independent supercratons, each with distinct amalgamation/break-up histories, of which Vaalbara is seen as one. While not necessarily disagreeing with the general concept of Bleeker (2003), we will later present arguments against a specific Vaalbara postulate.

It is quite often asserted in global literature (e.g., Leach et al., 2010 recently) that a majority of Precambrian earth scientists support the concept of a reducing palaeoatmosphere and -hydrosphere before $\sim 2.4 \mathrm{Ga}$, to be followed by the "Great Oxidation Event" (GOE) at some time between about 2.3 and $1.8 \mathrm{Ga}$ (well cited examples include: Holland, 1964, 1966, 1984, 1994, 2002; Cloud, 1968, 1973; Walker, 1977; Walker et al., 1983; Kasting, 1987, 2001; Kasting and Brown, 1998; Rye and Holland, 1998; Kasting and Siefert, 2002; Huston and Logan, 2004; Farquhar et al., 2010) (Fig. 1). In contrast, a much smaller group of workers, led by Dimroth and later by Ohmoto (e.g., Dimroth and Kimberley, 1976; Clemmey and Badham, 1982; Ohmoto, 1992, 1996, 1997, 1999, 2004; Lasaga and Ohmoto, 2002) argue for a single, much earlier Archaean rise in oxygen and relatively constant values thereafter. Despite ongoing debate on the timing of the GOE within a ca. 500 my chronological envelope, equally diverse disagreement on $\mathrm{pO}_{2}$ levels (e.g., Ohmoto, 2004 for a recent overview of the entire debate), never mind the alternative minority school of thought, conventional wisdom appears to have crystallized about a GOE at ca. 2.3-2.35 Ga which is applied at the global scale. In a recent review, Holland (2009) argues convincingly for the GOE having begun between 2.4 and $2.3 \mathrm{Ga}$. Of equal planetary scale is the concept of the first widespread glaciation at some time between ca. 2.4 (2.45?) and $2.2 \mathrm{Ga}$ (Fig. 1), with up to three possible glacial horizons, couched within a "Snowball Earth model" (e.g., Kirschvink, 1992; Hoffman et al., 1998) by a large segment of the scientific community, although the latter hypothesis has become somewhat watered down in its subsequent guise of the "Slushball Earth" due to conflicting data (e.g., Young, 2004).

While it is entirely logical that the widespread evidence on many cratons for glaciation at about this time supports a common global event, this is not an assumption that can be supported by hard chronological data at present, and it remains possible, remote though this may be seen by many perhaps, that glaciation was diachronous rather than a simultaneous and almost catastrophic "event" as implicit within the "Snowball Earth model" (SEM). Glaciation in better studied and much younger basins right up to the Pleistocene is generally accepted as spreading from centres of permanent ice cover over large adjacent realms, and then shrinking back towards the normally Polar locations of permanent permafrost; there is no reason intrinsically why this concept should not also apply to the Palaeoproterozoic glaciation and thus bring with it some measure of diachroneity. The point made is that there is no reason to doubt the strong evidence for glaciation across the planet in the Palaeoproterozoic; the door on debate, however should not be almost kept closed by the SEM nor should perfect global correlation be assumed as an absolute given. In this paper we thus wish to argue for a more complex character for the Neoarchaean-Palaeoproterozoic Earth and its preserved basin-fill record, and to plead for a more open debate and not mere acceptance of what appears to be a broad-based consensus. Analogously, while there is every reason to believe in the well founded and supported idea of a Neoarchaean "Kenorland", it is not necessary to extend this example into a general concept of universal planetary application; there should still be room to 
accept that some cratons might not have been part of this first inferred supercontinent (e.g., Eriksson et al., 2009a). More detailed examination of the proxies used to estimate Precambrian redox states are much more complex and will be explored later in this paper.

The paper therefore intends to examine briefly the Neoarchaean-Palaeoproterozoic geological record of the Kaapvaal craton, and to compare this with models for relatively uniform global scale Earth evolution. We will thus examine the supracrustal record of the Kaapvaal from about $2.7 \mathrm{Ga}$ to $\sim 1.8 \mathrm{Ga}$ with a view to debating how applicable such broad-based ideas might be to a classic Precambrian cratonic terrane.

\section{The supracrustal record of the Kaapvaal craton from $~ 2.7-1.8$ Ga: brief overview}

Formation of the Kaapvaal cratonic nucleus by 23.1 Ga (Fig. 2: Barberton-South and Barberton-North cratonic terranes) was succeeded by the accretion of composite terranes from both north (Murchison-North Kaapvaal terrane; Fig. 2) and west (modern orientations) (Fig. 2; Kimberley block) concomitant with formation of the Earth's oldest known large sedimentary depository, the Witwatersrand basin, from ca. 3.0 to ca. $2.7 \mathrm{Ga}$ (e.g., de Wit et al., 1992; Robb and Meyer, 1995; Zeh et al., 2009). A complex, double flexural foreland basin model is interpreted for the latter, encompassing the Witwatersrand Supergroup in its foredeep sub-basin and the Mozaan Group of the partly co-eval (Beukes and Cairncross, 1991) Pongola Supergroup in its back-bulge sub-basin (Catuneanu, 2001) (Fig. 3).

Two major mantle plumes, that of the ca. 2.7 Ga Ventersdorp Supergroup (cf. Hatton, 1995) and of the $2058 \pm 0.8 \mathrm{Ga}$ (Buick et al., 2001) Bushveld Complex, each related to global superplume events (e.g., Condie, 2004a; Eriksson et al., 2004), "bracket" evolution of the $\sim 2.66-2.05 \mathrm{Ga}$ Transvaal Supergroup supracrustals, preserved in three basins across the craton (Transvaal itself, Griqualand West, Kanye in Botswana - see Fig. 6; Catuneanu and Eriksson 1999, 2002; Eriksson et al., 2001, 2006). The Ventersdorp Supergroup was laid down on the Witwatersrand foredeep strata and surrounding cratonic rocks following a 100 my lacuna (Maphalala and Kröner 1993; Beukes and Nelson 1995) during which the Witwatersrand strata were subject to tectonic shortening and erosion (Hall, 1996; Eriksson et al., 2002). The basal $\sim 2 \mathrm{~km}$ thick, $2714 \pm 8 \mathrm{Ma}$ (Armstrong et al., 1991) Klipriviersberg Group flood basalts (Fig. 4b) include komatiites (van der Westhuizen et al., 1991). Crustal extension followed, forming fault-bounded basins accommodating an immature clastic sedimentary - bimodal volcanic lithological association, the unconformity-based, $2709 \pm 4$ Ma Platberg Group (Armstrong et al., 1991; van der Westhuizen et al., 1991) (Fig. 4b). Undated uppermost sheet-like sedimentary and volcanic units (respectively, the Bothaville and Allanridge Formations) testify to a final phase of thermal subsidence, minor komatiites in the latter supporting residual graben and plume influences (van der Westhuizen et al., 1991; Eriksson et al., 2002).

The ca. 2657-9 Ma and 2664 Ma (respectively, unpublished report, South African Committee for Stratigraphy; Barton et al., 1995) "protobasinal" (a descriptive appellation) successions, preserved within discrete fault-bounded depositories at the base of the Transvaal Supergroup basin-fill within the Transvaal preservational basin (TB) (Fig. 5), are considered possible time (Olsson et al., 2010) and geodynamic equivalents of

late-stage Ventersdorp deposits, formed within a wide rift zone beneath the Transvaal depository (e.g., Catuneanu and Eriksson, 1999). They have no equivalents beneath the 
other two Transvaal basins on the craton. Some of the protobasinal rocks have been affected by northward-directed tectonic shortening, apparently synchronous with deposition of the succeeding undated and unconformably-based Black Reef Formation (Eriksson et al., 2006).

Thin Black Reef sheet sandstones and lesser conglomerates (Fig. 5) also occur in the Kanye (KB) basin, where they form the base of the supergroup. These inferred fluvial deposits pass up into a thick transgressive epeiric marine succession (ChuniespoortTaupone Groups, respectively in TB and KB; equivalent Ghaap Group in Griqualand West basin; Fig. 6) (Button 1973; Key 1983; Henry et al., 1990; Els et al., 1995). The Schmidtsdrif Subgroup forms the base of the Transvaal succession in the Griqualand West basin (GB) with a lowermost clastic-chemical sedimentary Vryburg Formation (100-300m thick; minor 2642 \pm 3 Ma andesites; Walraven and Martini 1995), overlain by carbonate and mudrock formations (Fig. 8). The Schmidtsdrif palaeoenvironment varied from fluvial to either marginal marine (Beukes 1979) or deeper marine settings (Altermann and Siegfried 1997).

A transgressive epeiric sea advanced onto a large part of the Kaapvaal craton following Black Reef-Schmidtsdrif sedimentation, forming a thick platform-cover succession (Chuniespoort-Taupone-Ghaap Groups) $(<2642 \pm 3 \mathrm{Ma}-$ at least $2432 \pm 31 \mathrm{Ma}$, Trendall et al., 1990; 2.65-2.40 Ga, Knoll and Beukes, 2009) (Fig. 8). This comprised: (1) lowermost stromatolitic carbonate lithologies $(\sim 1200 \mathrm{~m}$ in TB, $>2.5 \mathrm{~km}$ in GB); (2) medial banded iron formations (BIF) ( 640 $\mathrm{m}$ in TB); (3) uppermost mixed siliciclastic and chemical sedimentary rocks ( $\leq 1100 \mathrm{~m}$ Duitschland Formation in TB - Fig. 5; Koegas Subgroup in GB) (Altermann and Siegfried 1997; Eriksson et al. 2001, 2006) (Fig. 8). Palaeoenvironmental settings varied from exposed peri-tidal flats to deep carbonate platform conditions (Eriksson and Altermann, 1998). Further transgression at ca. 2500 $\mathrm{Ma}$ (Fig. 8) drowned the carbonate platform and ushered in deposition of BIF across all three depositories (Altermann and Nelson, 1998). Final withdrawal of the epeiric sea off the Kaapvaal craton was coeval with deposition of mixed clastic and chemical sediments of the Koegas Subgroup (GB) and the Duitschland Formation (TB) (Eriksson et al., 2005).

The Koegas gradationally overlies the BIF in the Griqualand West basin, and comprises alternations of clastic deposits (ascribed to deltaic and shoreline [tidal] settings) and dolomites and BIF (interpreted as shelf deposits removed from clastic input) due to third-order sea level cyclicity (Beukes, 1983, 1984). An age of $2415 \pm 6 \mathrm{Ma}(\mathrm{Pb}-\mathrm{Pb}$; quoted by Kirschvink et al., 2000) is based on a personal communication. The Koegas lithologies have been deformed by a major thrusting event which did not penetrate higher into succeeding stratigraphy (cf., the Makganyene Formation - Fig. 8) (Altermann and Hälbich, 1990, 1991). The Duitschland Formation in the NE part of the Transvaal basin, although commonly correlated with the Koegas (Fig. 8), is undated; in contrast to the latter, it overlies an unconformity which extends down through uppermost cherty-shaly BIF (confusingly referred to as a carbonate-rich succession, the "Tongwane Formation" by Martini, 1977) in the upper Penge Iron Formation and oversteps regionally onto preceding carbonates (e.g., Potgieter, 1992; Hälbich et al., 1993). Gentle folding in the underlying ferruginous and carbonate units has led to locally apparently conformable relationships with Duitschland lithologies, but the unconformable relationship is clear in regional three-dimensional geometry (Hälbich et al., 1993). Correlation of the Koegas 
with the "Tongwane Formation" has further exacerbated stratigraphic confusion arising from the lower Duitschland contact. The Duitschland Formation is dominated by marls and mudrocks, with relatively abundant dolostones and limestones, minor relatively thin beds of quartzite and conglomerate, and two thin diamictites with the one at the base of the unit being considered glacigenic (Frauenstein et al., 2009) (Fig. 9); highly variable thicknesses $(15 \mathrm{~m}$ to ca. $1100 \mathrm{~m}$ are related to variation in the basal unconformable downcutting patterns across its limited outcrop area in the NE of the basin; Potgieter, 1992; Hälbich et al., 1993; Bekker et al., 2001; Frauenstein et al., 2009). This geometry, allied to the predominant marly composition of the Duitschland, suggest an origin related to major weathering and erosion of Chuniespoort chemical lithologies during the hiatus (estimated between ca. 80 my and 200 my; respectively, Eriksson et al., 2001; Mapeo et al., 2006) separating the Chuniespoort Group from the succeeding Pretoria Group (Eriksson et al., 2001).

In all three preservational Transvaal basins (Fig. 6), the rocks of the chemical sedimentary platform, including the localized Koegas Subgroup (GB only) and Duitschland Formation (TB only) which occur either at their upper part (Koegas) or unconformably overlie them (Duitschland), are unconformably succeeded by an essentially clastic sedimentary-lesser volcanic succession, known as the PretoriaPostmasburg-Segwagwa Groups (respectively in the TB, GB, KB) (e.g., Eriksson et al. 2006). At the base of the Pretoria Group (Fig. 5), the Rooihoogte Formation reflects a palaeo-karst - fill deposit, largely comprised of variably reworked weathered cherty detritus from the Chuniespoort carbonates, underlining the significant time gap between this chemical sedimentary group and the Pretoria succession. Eriksson et al. (2001) have noted a possible relationship between Duitschland deposits and the Rooihoogte, encompassing analogous source areas and genesis, despite the angular unconformity separating the two (a view shared by Bekker et al., 2001; Frauenstein et al., 2009). The lithostratigraphy, interpreted depositional environments and sequence stratigraphy of the Pretoria Group have been studied in some detail (e.g., Eriksson et al., 1991, 2001b, 2005, 2006; Eriksson and Reczko, 1995; Catuneanu and Eriksson, 1999; Moore et al., 2001) (Fig. 5). There are relatively widespread, minor lenticular occurrences of interpreted glacigenic beds within the upper part of the Timeball Hill Formation (Visser, 1971; Coetzee et al., 2006; Eriksson et al., 2006) (Figs. 5). These lithologies include not only diamictites (with striated pebbles), but also slumped wackes, conglomerates and varved shales (Visser, 1971; Eriksson et al., 1994) (Fig. 7). The profile shown in this figure comprises largely of diamictite where the sandy-silty mudstone matrix (95\% of volume) supports mainly chert clasts (remaining $5 \%$ ); clasts commonly exhibit orientation of long axes roughly parallel to regional bedding, and there are weak trends of upward-fining and decreased clast rounding upwards in the diamictite. These characteristics support reworking of glacial moraines and an overall periglacial setting (Visser, 1971).

The Pretoria Group succession is poorly dated: basal black shales (TB) at $2316 \pm 7 \mathrm{Ma}$ (Re-Os; Hannah et al., 2004); detrital zircons within successively higher sandstone units within the Kanye basin at 2250 $14 / 15$ Ma near the base, 2236 \pm 13 Ma in the middle, and $2193 \pm 20 \mathrm{Ma}$ in the upper part (Mapeo et al., 2006; comparable data in Dorland et al., 2004). A major floor basalt (Hekpoort-Tsatsu-Ongeluk Formations, respectively TB, KB, $\mathrm{GB}$ ) is common to all three basins and is dated at $2222 \pm 13 \mathrm{Ma}$ (in the GB; $\mathrm{Pb}-\mathrm{Pb}$; Cornell et al., 1996). Pretoria-Segwagwa sedimentation terminated prior to emplacement 
of the major layered mafic Bushveld Complex intrusion at $2058 \pm 0.8$ Ma (Buick et al., 2001) (Fig. 5), as evidenced from regional compressive deformation of the sedimentary strata (Bumby et al., 1998; Eriksson et al., 1998). The Postmasburg Group succession in the Griqualand West basin is truncated compared to the other two basins, and there is debate on correlation of this thinner basin-fill with that of the two sister depositories (e.g., Moore et al., 2001 for a discussion). In the GB, the lowermost Makganyene Formation (Fig. 8) diamictites overlie a high angle regional unconformity that locally penetrates through both Koegas and BIF units into the uppermost carbonate succession (Altermann and Nelson, 1998; Altermann, W., pers. comm., 2010). The Makganyene Formation exhibits highly variable thickness (mostly 3-70m, maximum of $500 \mathrm{~m}$ ) and comprises mostly of massive and coarsely bedded (seen through bedding parallel clast orientation) diamictites, associated with subordinate lenticular conglomerates, sandstones and mudrocks (locally varved) (Visser, 1971; Polteau et al., 2006) (Fig. 10). Although striations on large chert clasts, rafted stones and localised exposures of glacial pavements support a glacial origin (Visser, 1971, 1999; Eyles and Januszczak, 2004), a limited mountain glaciation (with fluvial and marine reworking) is inferred, centred on the Vryburg Rise between the Transvaal and Griqualand West sub-basins (Fig. 6) (Visser, 1971). In turn, these inferred glacial deposits are unconformably overlain by the Ongeluk Formation flood basalts (Fig. 8), for which a near-equatorial palaeomagnetic position has been inferred (Evans et al., 1997). The Ongeluk lavas are succeeded by the Hotazel (jaspillites, volcanic-exhalative Mn deposits) and Mooidraai (dolomites) Formations (Beukes, 1986), neither of which has an obvious correlate in the Pretoria Group (compare with Fig. 5).

Intrusion of the Bushveld Complex in north-central Kaapvaal was followed almost immediately by sedimentation within the two Waterberg basins, the large Main and smaller Middelburg depositories, both bounded by fundamental Archaean cratonic structures within Kaapvaal (Fig. 11); the basin-fills are dated between ca. 2.06 and 1.88 Ga (SACS, 1980; Jansen, 1982; Walraven and Hattingh, 1993; Eglington and Armstrong, 2004; Hanson et al., 2004). These basins form part of a global group of basin-fills marked by the first occurrences of red beds (indicating free oxygen in the extant atmosphere) as well as fully-developed erg deposits, at 2.0-1.8 Ga (e.g. Eriksson and Cheney, 1992; Eriksson and Simpson, 1998). Waterberg depositional palaeoenvironments were predominantly fluvial, with subordinate alluvial fan, lake and desert settings (Vos and Eriksson, 1977; Callaghan et al., 1991; Van der Neut and Eriksson, 1999; Simpson et al., 2002, 2004; Eriksson et al., 2008). Active tectonism including synsedimentary faulting strongly influenced Waterberg deposition (Jansen, 1975; Callaghan et al., 1991; Bumby et al., 2001, 2004), and prevailing palaeoclimatic conditions appear to have been essentially semi-arid (Callaghan et al., 1991; Simpson et al., 2002, 2004).

\section{Discussion}

\subsection{Kaapvaal craton and supercontinentality}

There is general agreement that the supercontinent cycle has a relation to mantle plume-type processes (e.g., Condie, 2004a, b; Condie et al., 2001; Zhong et al., 2007) and the plate tectonic paradigm, with the recent postulate of a critical role for the tectosphere 
(Santosh et al., 2009). These generalizations are in turn related to divergent views on the antiquity of a Phanerozoic-style plate tectonic regime (e.g., de Wit, 1998; Eriksson and Catuneanu, 2004) and possible models for the transition from thermally-dominated to plate tectonics-dominated geodynamic regimes (e.g., Trendall, 2002). Approaches applied to support postulates of Precambrian supercontinental assemblies include geochronology, matching of basin-fill stratigraphies or mobile belt segments on separate cratonic blocks, correlation of widespread impact ejecta/fallout units (e.g., Glikson, 2008), and palaeomagnetic techniques (e.g., Pesonen et al., 2003). However, spherule beds on two separate cratons does not necessarily imply juxtaposition, as they may reflect global-scale events (or even lesser scales of bolide-related fallout), and chronological equivalence is also not exclusively ascribable to amalgamation (Eriksson et al., 2009a). Palaeomagnetic studies are commonly accepted as a really quantitative means of testing postulated amalgamations of cratons, but such techniques are fraught with problems also, and their application to terranes older than $\sim 1.8 \mathrm{Ga}$ has been seriously questioned (e.g., Meert, 2002; see, however, Bleeker and Ernst, 2006; discussion in Eriksson et al., 2009a).

As discussed in the first paragraph of this paper, a "southern" supercontinent (incorporating Kaapvaal) has been inferred (e.g., Aspler and Chiarenzelli, 1998) as a necessary complement to the "northern" Kenorland amalgamation to support the concept of global supercontinentality emerging in the Neoarchaean. A comparison of the basic geology of all possible "southern" cratons that might have been amalgamated into this postulated supercontinent in the $\sim 3.1-2.8 \mathrm{Ga}$ interval provided no support for this Kenorland-analogy (Eriksson et al., 2009a). The latter authors and Nelson et al. (1999) also emphasized that there is an alternative explanation (to an assumption of contiguity) for similarities in geological character across ancient craton boundaries, namely that they can be ascribed to global events, such as superplume events (e.g., Condie, 2004a), eustatic and glaciation events (Eriksson et al., 2009a).

A small supercontinent, "Vaalbara" (expanded "Zimvaalbara" to include also, the Zimbabwe craton; Stanistreet, 1993; Cheney, 1996) representing conjunction of Pilbara and Kaapvaal cratons has enjoyed literature support (e.g., de Kock et al., 2009, recently). However, precise zircon chronology for the 3650-2200 Ma period does not support a Vaalbara assemblage, nor does palaeomagnetic data (never mind its possibly questionable application to rocks of this age) (Wingate, 1998; Nelson et al., 1999; Eriksson et al., 2009a). The other main discussion point in terms of possibly applying Neoarchaean supercontinentality to Kaapvaal is the evolution of the Limpopo mobile belt at the junction between the Zimbabwe and Kaapvaal cratons; within this belt, a highgrade Central Zone is flanked by Northern and Southern Marginal Zones (respectively, NMZ and SMZ), with the tripartite terrane orientated along an approximate ENE-WSW direction. There has been a long-running controversy on the age of the Limpopo belt collision between the two cratons, with two main proposed ages of ca. 2.6 Ga and ca. 2.0 Ga (e.g., de Wit et al., 1992; McCourt and Armstrong, 1998). Recent studies (e.g., Boshoff et al., 2006; Zeh et al., 2007; Perchuk et al., 2008; Van Reenen et al., 2008; Millonig et al., 2008; Gerdes and Zeh, 2009) provide unequivocal support for a Central Zone - Kaapvaal amalgamation at ca. 2.65-2.51 Ga, with a strong metamorphic overprint at ca. $2.03 \mathrm{Ga}$, which marked the much younger major collision between the Zimbabwe craton and the already assembled Kaapvaal-Central Zone plate (e.g., Jaeckel et al., 1997; Holzer et al., 1998; Kröner et al., 1999; Van Reenen et al., 2004; Zeh et al., 2004, 2007; 
Rigby et al., 2008a; Rigby, 2009). The earlier amalgamation of the small exotic plate of the Central Zone with Kaapvaal formed the SMZ, and the NMZ (as well as remobilization of the SMZ) occurred during the ca. $2.0 \mathrm{Ga}$ collision. The large igneous province record of Zimbabwe and Kaapvaal also supports their amalgamation having occurred at ca. 2.0 Ga (Söderlund et al., 2010).

The geological evidence currently available from the Kaapvaal craton does thus not provide strong support for any amalgamation of this craton prior to ca. $2.0 \mathrm{Ga}$, with strong evidence in favour of the latter age for such an event. Although examination of a single craton as done here, cannot be considered as very significant when pondering the concept of a global supercontinentality from the Neoarchaean, such a panacea view of Earth evolution should perhaps be considered as not necessarily pervasive at that time. The onset of the supercontinent cycle may thus have been diachronous, at least for some cratons (including Kaapvaal) (cf., Eriksson et al., 2009a).

\subsection{Kaapvaal craton and the "Great Oxidation Event" (GOE)}

Within the "mainstream" model of Neoarchaean-Palaeoproterozoic atmospheric evolution, the GOE is thought to have occurred at ca. 2.3-2.35 (-1.8) Ga. Within this "conventional" model the Earth's earliest large carbonate platforms (e.g., on Kaapvaal, the Malmani and Campbellrand Subgroups and equivalent in the Kanye basin; Fig. 8) are thought to have provided sinks for very high levels of $\mathrm{CO}_{2}$ in the Neoarchaean atmosphere (e.g., Falkowski and Raven, 1997). The concomitant precipitation of carbonate within these developing platforms would have had to overcome not only kinetic barriers but also the effects of inferred acidic seawater related to the palaeogreenhouse atmosphere (Wright and Altermann, 2000; Wright and Oren, 2005). It is postulated that this was only achieved due to significant changes in near-shore oceanic chemistry at about $2.5 \mathrm{Ga}$ made possible by the vast colonies of microbial organisms that arose as stable cratonic platforms emerged globally (whether in supercontinents or not) (Gandin et al., 2005; Gandin and Wright, 2007). Growing oxygen contents in the hydrosphere, initially (and atmosphere, subsequently) resulted from photosynthesis and as a consequence, banded iron formations (BIF; e.g., in the Asbesheuwels and Koegas Subgroups in GB and in the Penge [TB] and Hotazel [GB] Formations) formed in the more distal parts of the large epeiric seas on early cratons like Kaapvaal, where $\mathrm{Fe}^{2+}$, transported from deeper anoxic ocean basins, was precipitated (cf., Cloud, 1973; Kasting, 1987) beneath an as yet essentially anoxic palaeo-atmosphere. Within this classical model, the GOE occurred once oceanic iron had become oxidized and free oxygen accumulated within the atmosphere; the model is supported by the overall sedimentary succession on many of Earth's cratons of this age. Lyons et al. (2009) stress the possibility that deeper parts of the global ocean were oxygen-deficient and even euxinic, and that such conditions may have persisted for much if not the entire Proterozoic. Oxygenation of the hydrosphere may thus have been largely restricted to shallow, shelflike depths.

Also in support of the classic explanation for the GOE on the Kaapvaal craton, there is good evidence for iron pigmentation of the clastic sedimentary strata of both Pretoria and Waterberg Groups (Eriksson and Cheney, 1992). Within the former group, the colouration is restricted to matrix material (red beds sensu lato), while in the latter group, 
grain surfaces are stained partially red by iron oxides (red beds sensu stricto). This provides partisan evidence for a GOE at ca. 2.3-1.8 Ga, characterized by partially oxidizing palaeo-atmospheric conditions affecting Kaapvaal at least during early diagenesis of both groups of sediment, if not during deposition thereof. Physical evidence from Transvaal and Waterberg stratigraphies of Kaapvaal thus provides direct support of some of the major tenets of the classical GOE model at $\sim 2.3$ Ga (e.g., Karhu and Holland, 1996). Similarly, Lowe and Tice (2007) argue for a collapse of the greenhouse atmosphere after ca. $2.4 \mathrm{Ga}$, followed by global cooling, global ca. 2.4-2.2 Ga glaciation, and finally, permanent oxygenation of the palaeo-atmosphere.

However, despite data from Kaapvaal apparently supporting the classical and longstanding model of a ca. $2.3 \mathrm{Ga} \mathrm{GOE}$, it is this model itself which is currently being debated in the latest research, including new geochemical data derived from Kaapvaal supracrustal lithologies. Rapid fluctuation in pre-GOE Mo isotopic values (an oxygen proxy) from black shales from the Ghaap Group (Transvaal Supergroup, ca. 2.64-2.5 Ga; Fig. 8) have been taken to support the GOE, as they indicate rapid chemical changes in Neoarchaean oceans as frequently recurring oxygen-free conditions alternated with cyanobacterial production of oxygen (Voegelin et al., 2010). In direct contrast, however, Mo isotopic data from Ghaap Group carbonate rocks coeval with the black shales, show an opposite trend of constancy and support a near-continuous presence of oxygen, albeit at lower levels than in the black shales (Voegelin et al., 2010). The latter authors suggest that fluctuation of Mo isotopes in the black shales may rather reflect detrital inputs and concomitant dilution effects, or redox changes in the depositional environment, or both, thereby stressing the possible influence of basin-scale palaeoenvironmental influences. $\mathrm{Cr}$ isotopes (another accepted oxygen proxy) from Precambrian BIF indicate a transient rise in atmospheric and oceanic oxygen at ca. 2.8-2.6 Ga, prior to the GOE of 2.45-2.2 Ga, followed by a decline to pre-GOE levels again at ca. $1.8 \mathrm{Ga}$ (Frei et al., 2009). The GOE may thus have been a passing event, without necessarily leading to a first step-wise rise in global oxygen (Frei et al., 2009).

Support for the latter postulate is provided from field data derived from the Waterberg Group on Kaapvaal. Study of fluvial sediments within three formations of the Waterberg Group and from the Pretoria Group (Transvaal Supergroup) indicate locally elevated palaeoslope values for channel systems, allied to evidence for rapid, mass-flow type sedimentation, with inferred local ponding of muddy detritus in short-lived lakes (cf., Rainbird, 1992) (Eriksson et al., 2009b). The palaeoclimatic interpretation of such systems suggests a continuum of a greenhouse palaeo-atmosphere, at least for parts of Kaapvaal at ca. 2.3-1.8 Ga (Eriksson et al., 2009b). Physical (sedimentary) as opposed to (geo-)chemical evidence thus also questions a ca. $2.3 \mathrm{Ga} \mathrm{GOE}$ as a globally applicable universal occurrence. Eriksson et al. (2009b), while not negating the overall validity of enhanced oxygen levels in this general time period (ca. 2.4-1.8 Ga), argue rather for a diachronous change in global oxygen levels during the Palaeoproterozoic, which may possibly be a better model than the simple panacea of a universally applied 2.3 Ga GOE.

\subsection{Kaapvaal craton and a "Snowball Earth" glacigenic event at ca. 2.4-2.2 Ga}

The Proterozoic Eon was marked at its onset and termination by major glacial events, with evidence on many cratons for large continental ice sheets, and with sedimentological 
and palaeomagnetic data indicating that the ice may have extended to sea level, even at low latitudes (e.g., Evans et al., 1997; Williams and Schmidt, 1997; Schmidt and Williams, 1999; Sohl et al., 1999). Both major Proterozoic glaciogenic intervals correlate with inferred supercontinent rifting, and both also encompass thin yet widespread successions of limestone-dolostone ("cap carbonates" in SEH parlance) sharply overlying glacial or related deposits (e.g., Kirschvink, 1992; Hoffman et al., 1998). The observation of negative $\delta^{13} \mathrm{C}$ isotopic excursions in carbonate rocks within inferred glacial and related successions across many of the Palaeoproterozoic (and Neoproterozoic) cratons has served to support the SEH (e.g., Kaufman et al., 1991, 1997; Frimmel et al., 2002).

There are strong arguments against the elegant simplicity of the $\mathrm{SEH}$, notably those of Young (summary, 2004)) and those offered by Williams in many publications (synthesis, 2004). Some of their most cogent data arguing against the classic version of the SEH include: (1) strong evidence of seasonality; (2) thick successions of glacigenic deposits dominated by facies indicative of waterlain deposition accompanying glacial conditions; (3) gradual climatic change (rather than the abrupt and rapid changes implicit in the SEH) supported by geochemical and sedimentological evidence; (4) problematic spatial, chronological and genetic relations of BIF (inferred to follow on cap carbonate beds within the $\mathrm{SEH}$ ); (5) insufficient precise chronology to justify global correlations of discrete glacial horizons between and even within single cratonic terranes. The ultimate causes of global-scale glaciation in the Palaeoproterozoic (and Neoproterozoic for that matter) remain elusive (e.g., Young, 2004 and references therein; see, however the "large obliquity" postulate of Williams, e.g. 2004 and references therein).

Hambrey and Harland (1981) document at least three discrete glacial successions within the Palaeoproterozoic sedimentary record within the interval of $\sim 2.45-2.22 \mathrm{Ga}$. The best preserved example is from the Huronian Supergroup of Canada (where an association with long-lived rifting of the "Kenorland" supercontinent [Williams et al., 1991; Aspler and Chiarenzelli, 1998] has been proposed), while those from Kaapvaal while less complete, are also well studied (e.g., Visser, 1971; Bekker et al., 2001; Polteau et al., 2006). Examination of the nature of the glacigenic deposits from Kaapvaal (examples shown in Figs. 7,9 and 10) indicates a strong spatial (and thus also chronological) association with waterlain facies such as varved shales, glacio-fluvial conglomerates, laminated mudrocks (see also, Visser, 1971; Polteau et al., 2006); while not necessarily regular enough or on a scale suitable to indicate any observable measure of seasonality, these characteristics of the Kaapvaal deposits do compare favourably with points \#'s 2 and 3 in the previous paragraph. In addition, neither Makganyene Formation diamictites not those in the upper part of the Timeball Hill Formation of the Transvaal Supergroup show any relationship with cap carbonates or BIF. For the Duitschland Formation (Fig. 9) the thin lower diamictite (interpreted as being glacigenic) is succeeded by breccias and clastic sedimentary rocks, but the upper diamictite is overlain directly by a carbonate bed; however, this diamictite is generally not interpreted as having any evidence for glacial deposition (Frauenstein et al., 2009 and references therein). The Duitschland Formation (and its diamictites) are undated; those from the upper Timeball Hill Formation are separated by almost $2 \mathrm{~km}$ of stratigraphic thickness from the dated lowermost Timeball Hill shales (2316 \pm 7 Ma; Re-Os; Hannah et al., 2004); the Makganyene Formation diamictites are not directly dated and are overlain, unconformably, by the Ongeluk flood basalts (2222 $\pm 13 \mathrm{Ma}$; Pb-Pb; Cornell et al., 1996). 
Chronological constraints on the Kaapvaal Palaeoproterozoic glacial successions thus fits the general paucity of age data applicable to these beds globally. A strong case for the SEH cannot be made on the basis of the glacigenic deposits preserved within the Transvaal basins of the Kaapvaal craton, as outlined above. Opponents of this panacea theory such as Young (e.g., 2004 and references therein) stress that alternative geodynamic influences such as an association with rifting and the early onset of the supercontinent cycle in the Palaeoproterozoic appear to be relevant. Certainly, modeling of the geodynamic setting of the Pretoria Group basin does support a rift-related setting (e.g., Catuneanu and Eriksson, 1999; Eriksson et al., 2001; Fig. 5). However, there are no data to support a similar setting for either Makganyene or Duitschland Formations. In addition, as outlined earlier in this paper (and elsewhere; e.g., Eriksson et al., 2009a), a supercontinental affinity for Kaapvaal during the Palaeoproterozoic does not appear to be well supported by general geological data, nor precise chronology or (probably) imprecise palaeomagnetic data.

\section{Conclusions}

Condie et al. (2009) have argued in favour of a possibly global scale magmatic shutdown from ca. 2.45-2.2 Ga; the geodynamic changes wrought by such an event would have impacted greatly on palaeo-atmospheric and-hydrospheric systems also, and offer a possible scenario to accommodate the "Great Oxidation Event" (GOE; at ca. 2.4$2.3 \mathrm{Ga}$; Holland, 2009) and the first global-scale glaciation. Such a postulated global shutdown or even slowdown of the mantle thermal - plate tectonic engine of Earth could also explain the inferred protracted breakup of the Kenorland supercontinent (from ca. 2.45- $2.21 \mathrm{Ga}$; Aspler and Chiarenzelli, 1998). It could also explain why perhaps there was no "southern" equivalent to this inferred first cratonic amalgamation, and why the evidence from both Kaapvaal and Pilbara seems not to support any kind of "Vaalbara" assembly (for an alternative view, see Bleeker, 2003). Any significant slowdown (or even the extreme shutdown) of the plate tectonic and thermal systems would have worked against major plate movements and supercontinental assemblies in the ca. 2.45$2.2 \mathrm{Ga}$ period. Such an event, which was on the geological time scale a passing influence, could also explain the possible return of post-GOE oxygen levels in the extant atmosphere and hydrosphere to values similar to those that prevailed prior to the GOE (as proposed by Frei et al., 2009).

Evidence from the Kaapvaal craton suggests that supercontinentality was not a global phenomenon until possibly ca. $2.0 \mathrm{Ga}$, and that the onset of this cyclicity was diachronous on the global scale prior to that. Analogously, evidence (such as the studied fluvial systems of ca. $2.3-1.8 \mathrm{Ga}$ age) from Kaapvaal suggests that greenhouse palaeoclimatic conditions may have persisted there through this period, and that a possible GOE might also have been diachronous on the global scale. Study of the Palaeoproterozoic glacial deposits from this craton do not provide any real support for the "Snowball Earth Hypothesis" (SEH), and the current lack of precise chronological data both for this craton's glacial deposits and those of global scale, do not allow any judgement of whether these freezing events were real piercing points in the geological time scale or whether they too were diachronous from craton to craton. 
In conclusion, this paper strives to underline the complexity of events such as the SEH or the GOE, and of the onset of the supercontinent cycle - while they each make an attractive candidate for global events of significant chronological precision, thereby enabling a definite framework to be applied to the evolution of the NeoarchaeanPalaeoproterozoic Earth at this time, this might be an over-simplification through widespread acceptance of panacea-type hypotheses. We suggest that such events while real and generally of widespread if not necessarily always global compass, may have been diachronous events at the planetary scale; their possible application for correlation and relative dating should thus be treated with some caution.

\section{Acknowledgements}

PGE, NL and AJB acknowledge generous research funding from the National Research Foundation and University of Pretoria, South Africa. We thank Thino Rajab for drafting the figures, and an anonymous referee as well as Associate Editor Arie Croitoru for their valuable inputs.

\section{References}

Altermann, W., Hälbich, I.W., 1990. Thrusting, folding and stratigraphy of the Ghaap Group along the southwestern margin of the Kaapvaal Craton. South African Journal of Geology 93, 553-556.

Altermann, W., Hälbich, I.W., 1991. Structural history of the southwestern corner of the Kaapvaal Craton and the adjacent Namaqua realm: new observations and reappraisal. Precambrian Research 52, 133-166.

Altermann, W., Nelson, D.R., 1998. Sedimentation rates, basin analysis and regional correlations of three Neoarchaean and Palaeoproterozoic sub-basins of the Kaapvaal craton as inferred from precise U-Pb zircon ages from volcaniclastic sediments. Sedimentary Geology 120, 225-256.

Altermann, W., Siegfried, H.P., 1997. Sedimentology, facies development and typesection of an Archaean shelf-carbonate platform transition, Kaapvaal Craton, as deduced from a deep borehole core at Kathu, South Africa. Journal of African Earth Sciences 24, p. 391-410.

Armstrong, R.A., Compston, W., Retief, E.A., Williams, I.S., Welke, H.J., 1991. Zircon ion microprobe studies bearing on the age and evolution of the Witwatersrand Triad. Precambrian Research 53, 243-266.

Aspler, L.B., Chiarenzelli, J.R., 1998. Protracted breakup of Kenorland, a Neoarchean supercontinent? Geochronologic, tectonostratigraphic and sedimentologic evidence from the Paleoproterozoica. Sedimentary Geology 120, 75-104. 
Barton, J.M. Jr., Blignaut, E., Salnikova, E.B., Kotov, A.B., 1995. The stratigraphical position of the Buffelsfontein Group based on field relationships and chemical and geochronological data. South African Journal of Geology 98(4), 386-392.

Bekker, A., Kaufman, A.J., Karhu, J.A., Beukes, N.J., Swart, Q.D., Coetzee, L.L., Eriksson, K.A., 2001. Chemostratigraphy of the Paleoproterozoic Duitschland Formation, South Africa: implications for coupled climate change and carbon cycling. American Journal of Science 301, 261-285.

Beukes, N.J., 1979. Litostratigrafiese onderverdeling van die Schmidtsdrif-Subgroep van die Ghaap-Groep in Noord-Kaapland. Transactions of the Geological Society of South Africa 82, 313-327.

Beukes, N.J., 1983. Paleoenvironmental setting of iron formations in the depositional basin of the Transvaal Supergroup, South Africa, In: Trendall, A.F., Morris, R.CA. (Eds.) Iron-Formation: Facts and Problems. Elsevier, Amsterdamm, pp. 131-210.

Beukes, N.J., 1984. Sedimentology of the Kuruman and Griquatown iron-formations, Transvaal Supergroup, Griqualand West, South Africa. Precambrian Research 24, 47-84.

Beukes, N.J., 1986. The Transvaal Sequence in Griqualand West. In: Anhaeusser, CA.R., Maske, S. (Eds.) Mineral Deposits of Southern Africa, vol. 1. Geological Society of South Africa, Johannesburg, pp. 819-828.

Beukes, N.J., Cairncross, B., 1991. A lithostratigraphic-sedimentological reference profile for the Late Archaean Mozaan Group, Pongola Sequence: application to sequence stratigraphy and correlation with the Witwatersrand Supergroup. South African Journal of Geology 94, 44-69.

Beukes, N.J., Nelson, J.P., 1995. Sea-level fluctuation and basin subsidence controls on the setting of auriferous palaeoplacers in the Archaean Witwatersrand Supergroup: A genetic and sequence stratigraphic approach. Abstract, Centennial Geocongress, Johannesburg, Geological Society of South Africa, p. 860-863.

Bleeker, W., 2003. The late Archean record: a puzzle in ca. 35 pieces. Lithos 71, 99-134.

Bleeker, W., Ernst, R.E., 2006. Short-lived mantle generated magmatic events and their dyke swarms: The key unlocking Earth's paleogeographic record back to $2.6 \mathrm{Ga}$. In: Hanski, E., Mertanen, S., Rämö, T., Vuollo, J. (Eds.), Dyke Swarms - Time Markers of Crustal Evolution. A.A. Balkema, Rotterdam, pp. 3-26.

Boshoff, R., van Reenen, D.D., Smit, CA.A., Perchuk, L.L., Kramers, J.D., Armstrong, R., 2006. Geologic history of the Central Zone of the Limpopo Complex: the West Alldays area. Journal of Geology 114, 699-716. 
Buick, I.S., Maas, R., Gibson, R., 2001. Precise U-Pb titanite age constraints on the emplacement of the Bushveld Complex, South Africa. Journal of the Geological Society, London 158, 3-6.

Bumby, A.J., Eriksson, P.G., van der Merwe, R., 1998. Compressive deformation in the floor rocks to the Bushveld Complex (South Africa): evidence from the Rustenburg Fault Zone. Journal of African Earth Sciences 27, 307-330.

Bumby, A.J., Eriksson, P.G., van der Merwe, R., Brümer, J.J., 2001. Shear-zone controlled basins in the Blouberg area, Northern Province, South Africa: syn- and posttectonic sedimentation relating to ca. 2.0 Ga reactivation of the Limpopo Belt. Journal of African Earth Sciences 33, 445-461.

Bumby, A.J., Eriksson, P.G., van der Merwe, R., 2004. The early Proterozoic sedimentary record in the Blouberg area, Limpopo Province, South Africa; implications for the timing of the Limpopo orogenic event. Journal of African Earth Sciences 39, 123131.

Button, A., 1973. A regional study of the stratigraphy and development of the Transvaal Basin in the eastern and northeastern Transvaal. $\mathrm{PhD}$ thesis, University of the Witwatersrand, Johannesburg, p. 352.

Callaghan, CA.CA., Eriksson, P.G., Snyman, CA.P., 1991. The sedimentology of the Waterberg group in the Transvaal, South Africa: an overview. Journal of African Earth Sciences 13, 121-139.

Catuneanu, O., 2001. Flexural partitioning of the Late Archaean Witwatersrand foreland system, South Africa. Sedimentary Geology 141-142, 95-112.

Catuneanu, O., Eriksson, P.G., 1999. The sequence stratigraphic concept and the Precambrian rock record: an example from the 2.3-2.1 Ga Pretoria Group, Kaapvaal craton. Precambrian Research 97, 215-251.

Catuneanu, O., Eriksson, P.G., 2002. Sequence stratigraphy of the Precambrian Rooihoogte-Timeball Hill rift succession, Transvaal Basin, South Africa. Sedimentary Geology 147, 71-88.

Cheney, E.S., 1996. Sequence stratigraphy and plate tectonic significance of the Transvaal succession of southern Africa and its equivalent in Western Australia. Precambrian Research 79, 3-24.

Clemmey, H., Badham, J.P.N., 1982. Oxygen in the Precambrian atmosphere: an evaluation of the geological evidence. Geology 10, 141-146.

Cloud, P.E., 1968. Atmospheric and hydrospheric evolution on the primitive earth. Science 160, 729-736. 
Cloud, P.E., 1973. Paleoecological significance of banded iron-formation. Economic Geology 68, 1135-1143.

Coetzee, L.L., Beukes, N.J., Gutzmer, J., Kakegawa, T., 2006. Links of organic carbon cycling and burial to depositional depth gradients and establishment of a snowball Earth at $2.3 \mathrm{Ga}$. Evidence from the Timeball Hill Formation, Transvaal Supergroup, South Africa. South African Journal of Geology 109, 109-122.

Condie, K.CA., 2004a. Precambrian superplume events. In: Eriksson, P.G., Altermann, W., Nelson, D.R., Mueller, W.U., Catuneanu, O. (Eds.), The Precambrian Earth: Tempos and Events, Developments in Precambrian Geology 12. Elsevier, Amsterdam, pp. 163173.

Condie, K.CA., 2004b. Supercontinents and superplume events: distinguishing signals in the geological record. Physics of the Earth and Planetary Interiors 146, 319-332.

Condie, K.CA., Des Marais, D.J., Abbott, D., 2001. Precambrian superplumes and supercontinents: a record in black shales, carbon isotopes and paleoclimates? Precambrian Research 106, 239-260.

Condie, C.K., O'Neill, C., Aster, R., 2009b. Evidence and implications for a widespread magmatic shutdown for 250 My on Earth. Earth and Planetary Science Letters 282, 294298.

Cornell, D.H., Schütte, S.S., Eglington, B.L., 1996. The Ongeluk basaltic andesite formation in Griqualand West, South Africa: submarine alteration in a $2222 \mathrm{Ma}$ Proterozoic sea. Precambrian Research 79, 101-123.

De Kock, M.O., Evans, D.A.D., Beukes, N.J., 2009. Validating the existence of Vaalbara in the Neoarchean: Precambrian Research 174, 145-154.

De Wit, M.J., 1998. On Archean granites, greenstones, cratons and tectonics: does the evidence demand a verdict? Precambrian Research 91, 181-226.

De Wit, M.J., Roering, CA., Hart, R.J., Armstrong, R.A., De Ronde, R.E.J., Green, R.W.E., Tredoux, M., Perberdy, E., Hart, R.A., 1992. Formation of an Archaean continent. Nature 357, 553-562.

Dimroth, E., Kimberley, M.M., 1976. Precambrian atmospheric oxygen: evidence in the sedimentary distributions of carbon, sulfur, uranium, and iron. Canadian Journal of Earth Sciences 13, 1161-1185.

Eglington, B.M., Armstrong, R.A., 2004. The Kaapvaal Craton and adjacent orogens, southern Africa: a geochronological database and overview of the geological development of the craton. South African Journal of Geology 107, 13-32. 
Els, B.G., van den Berg, W.A., Mayer, J.J., 1995. The Black Reef Quartzite Formation in the western Transvaal: sedimentological and economic aspects, and significance for basin evolution. Mineralium Deposita 30, p. 112-123.

Eriksson, K.A., Simpson, E.L., 1998. Controls on spatial and temporal distribution of Precambrian aeolianites. Sedimentary Geology 120, 275-294.

Eriksson, P.G., Altermann, W., 1998. An overview of the geology of the Transvaal Supergroup dolomites (South Africa). Environmental Geology 36(1-2), 179-188.

Eriksson, P.G., Catuneanu, O., 2004. A commentary on Precambrian plate tectonics. In: Eriksson, P.G., Altermann, W., Nelson, D.R., Mueller, W.U., Catuneanu, O. (Eds.), The Precambrian Earth: Tempos and Events. Developments in Precambrian Geology 12, Elsevier, Amsterdam, pp. 201-213.

Eriksson, P.G., Cheney, E.S., 1992. Evidence for the transition to an oxygen-rich atmosphere during the evolution of red beds in the Lower Proterozoic sequences of southern Africa. Precambrian Research 54, 257-269.

Eriksson, P.G., Reczko, B.F.F., 1995. The sedimentary and tectonic setting of the Transvaal Supergroup floor rocks to the Bushveld complex. Journal of African Earth Sciences 21, 487-504.

Eriksson, P.G., Schreiber, U.M., Van der Neut, M., 1991. A review of the sedimentology of the Early Proterozoic Pretoria Group, Transvaal Sequence, South Africa. Implications for tectonic setting. Journal of African Earth Sciences 13, 107-119.

Eriksson, P.G., Reczko, B.F.F., Merkle, R.K.W., Schreiber, U.M., Engelbrecht, J.P., Res, M., Snyman, CA.P., 1994. Early Proterozoic black shales of the Timeball Hill Formation, South Africa: volcanogenic and palaeoenvironmental influences. Journal of African Earth Sciences 18, 325-337.

Eriksson, P.G., van der Merwe, R., Bumby, A.J., 1998. The Palaeoproterozoic Woodlands Formation of eastern Botswana - northwestern South Africa: lithostratigraphy and relationship with Transvaal basin inversion structures. Journal of African Earth Sciences 27(3-4), 349-358.

Eriksson, P.G., Altermann, W., Catuneanu, O., van der Merwe, R., Bumby, A.J., 2001. Major influences on the evolution of the 2.67-2.1 Ga Transvaal basin, Kaapvaal craton. Sedimentary Geology 141-142, 205-231.

Eriksson, P.G., Condie, K.CA., Westhuizen, W.V.D., Merwe, R.V.D., Bruiyn, H.D., Nelson, D.R., Altermann, W., Cunningham, M.J., 2002. Late Archaean superplume events: A Kaapvaal-Pilbara perspective. Journal of Geodynamics 34, 207-247. 
Eriksson, P.G., Catuneanu, O., Nelson, D.R., Mueller, W.U., Altermann, W., 2004. Towards a synthesis. In: Eriksson, P.G., Altermann, W., Nelson, D.R., Mueller, W.U., Catuneanu, O. (Eds.), The Precambrian Earth: tempos and events, Developments in Precambrian Geology 12. Elsevier, Amsterdam, pp. 739-769.

Eriksson, P.G., Catuneanu, O., Els, B.G., Bumby, A.J., Van Rooy, J.L., Popa, M., 2005. Kaapvaal Craton: Changing first- and second-order controls on sea level from 3.0 Ga to 2.0 Ga. Sedimentary Geology 176, 121-148.

Eriksson, P.G., Altermann, W., Hartzer, F.J., 2006. The Transvaal Supergroup and its precursors, In: Johnson, M.R., Anhaeusser, CA.R., Thomas, R.J. (Eds.) The Geology of South Africa. Geological Society of South Africa, Johannesburg and Council for Geoscience, Pretoria, pp. 237-260.

Eriksson, P.G., Banerjee, S., Catuneanu, O., Sarkar, S. Bumby, A.J., Mtimkulu, M.N., 2007. Prime controls on Archaean-Palaeoproterozoic sedimentation: Change over time. Gondwana Research 12, 550-559.

Eriksson, P.G., Long, D.G.F., Bumby, A.J., Eriksson, K.A.E., Simpson, E.L., Catuneanu, O., Claassen, M., Mtimkulu, M.N., Mudziri, K.T., Brümer, J.J., van der Neut, M., 2008. Palaeohydrological data from the ca. 2.0-1.8 Ga Waterberg Group, South Africa: discussion of a possibly unique Palaeoproterozoic fluvial style. South African Journal of Geology 111(2-3), 281-304.

Eriksson, P.G., Banerjee, S., Nelson, D.R., Rigby, M.J., Catuneanu, O., Sarkar, S., Roberts, R.J., Ruban, D., Mtimkulu, M.N., Sunder Raju, P.V., 2009a. A Kaapvaal craton debate: Nucleus of an early small supercontinent or affected by an enhanced accretion event? Gondwana Research 15, 354-372.

Eriksson, P.G., Rautenbach, CA.J.deW., Wright, D.T., Bumby, A.J., Catuneanu, O., Mostert, P., van der Neut, M., 2009b. Possible evidence for episodic epeiric marine and fluvial sedimentation (and implications for palaeoclimatic conditions), ca. 2.3-1.8 Ga, Kaapvaal craton, South Africa. Palaeogeography, Palaeoclimatology, Palaeoecology 273, 153-173.

Evans, D.A., Beukes, N.J., Kirschvink, J.L., 1997. Low latitude glaciation in the Palaeoproterozoic era. Nature 386, 262-266.

Eyles, N., Januszczak, N., 2004. 'Zipper-rift': A tectonic model for Neoproterozoic glaciations during the breakup of Rodinia after 750 Ma. Earth-Science Reviews 65(1-2), $1-73$.

Falkowski, P. G., Raven, J. A., 1997. Aquatic Photosynthesis. Blackwell, Oxford, p. 375. 
Farquhar, J., Namping, W., Canfield, D.E., Oduro, H., 2010. Connections between sulfur cycle evolution, sulfur isotopes, sediments, and base metal sulfide deposits. Economic Geology 105, 509-533.

Frauenstein, F., Veizer, J., Beukes, N., van Niekerk, H.S., Coetzee, L.L., 2009. Transvaal Supergroup carbonates: Implications for Paleoproterozoic $\delta^{18} \mathrm{O}$ and $\delta^{13} \mathrm{C}$ records. Precambrian Research 175, 149-160.

Frei, R., Gaucher, CA., Poulton, S.W., Canfield, D.E., 2009. Fluctuations in Precambrian atmospheric oxygenation recorded by chromium isotopes. Nature 461, 250-253.

Frimmel, H.E., Fölling, P.G., Eriksson, P.G., 2002. Neoproterozoic tectonic and climatic evolution recorded in the Gariep Belt, Namibia and South Africa. Basin Researc 14, 5567.

Gandin, A., Wright, D.T., 2007. Evidence of vanished evaporites in Neoarchaean carbonates of South Africa. In: Schreiber, B.CA., Lugli, S., Babel, M. (Eds.), Evaporites through Space and Time. Geological Society London Special Publication 285, pp. 285308.

Gandin, A., Wright, D.T., Melezhik, V., 2005. Vanished evaporites and carbonate formation in the Neoarchaean Kogelbeen and Gamohaan formations of the Campbellrand Subgroup, South Africa. Journal of African Earth Sciences 41, 1-23.

Gerdes, A., Zeh, A., 2009. Zircon formation versus zircon alteration - new insights from combined U-Pb and Lu-Hf in situ LA-ICP-MS analyses, and consequences for the interpretation of Archean zircon from the Limpopo Belt. Chemical Geology 261, 230243.

Glikson, A.Y., 2008. Field evidence of Eros-scale asteroids and impact-forcing of Precambrian geodynamic episodes, Kaapvaal (South Africa) and Pilbara (Western Australia) cratons. Earth and Planetary Science Letters 267, 558-570.

Hälbich, I.W., Scheepers, R., Lamprecht, D.F., van Deventer, J.L., De Kock, N.J., 1993. The Transvaal-Griqualand West banded iron formation: geology, genesis, iron exploitation. Journal of African Earth Sciences 16, 63-120.

Hall, R.CA.B., 1996. The stratigraphic placement of the Venterspost Conglomerate Formation. MSc thesis (unpubl.), Potchefstroom University for Christian Higher Education, South Africa, p. 153.

Hambrey, M. J., Harland, W.B. (Eds.), 1981. Earth's pre-Pleistocene glacial record. Cambridge University Press, Cambridge U.K., p. 1004. 
Hannah, J.L., Bekker, A., Stein, H.J., Markey, R.J., Holland, H.D., 2004. Primitive Os and $2316 \mathrm{Ma}$ age for marine shale: implications for Paleoproterozoic glacial events and the rise of atmospheric oxygen. Earth and Planetary Science Letters 225, 43-52.

Hanson, R.E., Gose, W.A., Crowley, J., Ramezani, S.A., Bowring, D.S., Hall, R.P., Pancake, J.A., Mukwakwami, J., 2004. Paleoproterozoic intraplate magmatism and basin development on the Kaapvaal Craton: Age, paleomagnetism and geochemistry of $\sim 1.93$ to $\sim 1.87$ Ga post-Waterberg dolerites. South African Journal of Geology 107, 233-254.

Hatton, CA.J., 1995. Mantle plume origin for the Bushveld and Ventersdorp magmatic provinces. Journal of African Earth Sciences 21, 571-577.

Henry, G., Clendenin, CA.W., Charlesworth, E.G., 1990. Depositional facies of the Black Reef Quartzite Formation in the eastern Transvaal. Abstract, 23rd Geocongress, Geological Society of South Africa, Cape Town, p. 234-237.

Hoffman, P. F., Kaufman, A. J., Halverson, G. P., Schrag, D. P., 1998. A Neoproterozoic Snowball Earth. Science 281, 1342-1346.

Holland, H.D., 1964. On the chemical evolution of the terrestrial and Cytherean atmosphere. In: Brancazio, P.J., Cameron, A.G.W. (Eds.), The Origin and Evolution of Atmospheres and Oceans. John Wiley, Chichester, pp. 86-97.

Holland, H.D., 1966. Origin and evolution of the atmosphere. McGraw-Hill 1966 Yearbook, Science and Technology, p. 53-59.

Holland, H.D., 1984. The Chemical Evolution of the Atmosphere and the Oceans. Princeton University Press, Princeton, New Jersey, p. 582.

Holland, H.D., 1994. Early Proterozoic atmospheric change. In: Bengston, S. (Ed.), Early life on Earth. Nobel Symposium No. 84. Columbia Univ. Press, New York, pp. 237-244.

Holland, H.D., 2002. Volcanic gases, black smokers, and the great oxidation event. Geochimica et Cosmochimica Acta 66, 3811-3826.

Holland, H.D., 2009. Why the atmosphere became oxygenated: A proposal. Geochimica et Cosmochimica Acta 73, 5241-5255.

Holzer, L., Frei, R., Barton, J.M., Kramers, J.D., 1998. Unraveling the record of successive high grade events in the Central Zone of the Limpopo Belt using $\mathrm{Pb}$ single phase dating of metamorphic minerals. Precambrian Research 87, 87-115.

Huston, D.L., Logan, G.A., 2004. Barite, BIFs and bogs: Evidence for the evolution of the Earth's early hydrosphere. Earth and Planetary Science Letters 220, 41-55. 
Jaeckel, P., Kröner, A., Kamo, S.L., Brandl, G., Wendt, J.I., 1997. Late Archaean to early Proterozoic granitoid magmatism and high-grade metamorphism in the central Limpopo belt, South Africa. Journal of the Geological Society of London 154, 25-44.

Jansen, H., 1975. Precambrian basins on the Transvaal craton and their sedimentological and structural features. Transactions of the Geological Society of South Africa 78, 25-33.

Jansen, H., 1982. The geology of the Waterberg Basin in the Transvaal, Republic of South Africa. Memoir of the Geological Survey of South Africa 71, p. 98.

Karhu, J.A., Holland, H.D., 1996. Carbon isotopes and the rise of atmospheric oxygen. Geology 24, 867-870.

Kasting, J.F., 1987. Theoretical constraints on oxygen and carbon dioxide concentrations in the Precambrian atmosphere. Precambrian Research 34, 205-229.

Kasting, J.F., 2001. Earth history: The rise of atmospheric oxygen. Science 293, 819-820.

Kasting, J.F., Brown, L.L., 1998. The early atmosphere as a source of biogenic compounds. In: Brack, A. (Ed.), Molecular Origins of Life. Cambridge University Press, Cambridge, U.K., pp. 35-56.

Kasting, J.F., Siefert, J.L., 2002. Life and the evolution of Earth's atmosphere. Science 296, 1066-1068.

Kaufman, A.J., Hayes, J.M., Knoll, A.H., Germs, G.J.B., 1991. Isotopic composition of carbonates and organic carbon from upper Proterozoic successions in Namibia: stratigraphic variation and the effects of diagenesis and metamorphism. Precambrian Research 4, 301-327.

Kaufman, A.J., Knoll, A.H., Narbonne, G.M. 1997. Isotopes, ice ages, and Neoproterozoic Earth history. Proceedings of the National Academy of Sciences, USA 94, 6600-6605.

Key, R.M., 1983. The geology of the area around Gaborone and Lobatse, Kweneng, Kgatleng, Southern and South East Districts. Geological Survey of Botswana District Memoir 5, Gaborone, p. 229.

Kirschvink, J. L., 1992. Late proterozoic low-latitude global glaciation: The snowball Earth. In: Schopf, J.W., Klein, CA. (Eds.), The Proterozoic Biosphere: a multidisciplinary study. Cambridge University Press, Cambridge, pp. 51-52.

Kirschvink, J.L., Gaidos, E.J., Bertani, L.E., Beukes, N.J., Gutzmer, J., Maepa, L.N., Steinberger, R.E., 2000. Paleoproterozoic snowball Earth: Extreme climatic and geochemical global change and its biological consequences. Proceedings of the National Academy of Sciences of the United States of America 97/4, 1400-1405. 
Knoll, A.H., Beukes, N.J., 2009. Introduction: Initial investigations of a Neoarchean shelf margin-basin transition (Transvaal Supergroup, South Africa). Precambrian Research 169(1-4), 1-14.

Kröner, A., Jaeckel, P., Brandl, G., Nemchin, A.A., Pidgeon, R.T., 1999. Single zircon ages for granitoid gneisses in the Central Zone of the Limpopo Belt, Southern Africa and geodynamic significance. Precambrian Research 93, 299-337.

Lasaga, A.CA., Ohmoto, H., 2002. The oxygen geochemical cycle: dynamics and stability. Geochimica et Cosmochimica Acta 66, 361-381.

Leach, D.L., Bradley, D.CA., Huston, D., Pisarevsky, S.A., Taylor, R.D., Gardoll, S.J., 2010. Sediment-hosted Lead-Zinc deposits in Earth history. Economic Geology 105, 593625.

Lowe, D.R., Tice, M.M., 2007. Tectonic controls on atmospheric, climatic, and biological evolution 3.5-2.4 Ga. Precambrian Research 158, 177-197.

Lyons, T.W., Anbar, A.D., Severmann, S., Scott, C., Gill, B.C., 2009. Tracking euxinia in the ancient ocean: A multiproxy perspective and Proterozoic case study. Annual Review of Earth and Planetary Sciences 37, 507-534.

Mapeo, R.B.M., Armstrong, R.A., Kampunzu, A.B., Modisi, M.P., Ramokate, L.V., Modie, B.N.J., 2006. A ca. 200 Ma hiatus between the Lower and Upper Transvaal Groups of southern Africa: SHRIMP U-Pb detrital zircon evidence from the Segwagwa Group, Botswana: Implications for Palaeoproterozoic glaciations. Earth and Planetary Science Letters 244, 113-132.

Maphalala, R.M., Kröner, A., 1993. Pb-Pb single zircon ages for the Younger Archaean granitoids of Swaziland. Abstract, $16^{\text {th }}$ Colloquium on African Geology, Geological Society of Africa, Mbabane, Swaziland, v. 2, p. 201-206.

Martini, J.E.J., 1977. A copper-bearing horizon in the Pretoria Group in the north-eastern Transvaal. Abstract, Geocongress 77, Geological Society of South Africa, Johannesburg, p. $57-59$.

McCourt, S., Armstrong, R.A., 1998. SHRIMP U-Pb zircon geochronology of granites from the Central Zone, Limpopo Belt, southern Africa: implications for the age of the Limpopo Orogeny. South African Journal of Geology 101, 329-338.

Meert, J.G., 2002. Paleomagnetic evidence for a Paleo-Mesoproterozoic supercontinent. Gondwana Research 5, 207-215. 
Millonig, L., Zeh, A., Gerdes, A., Klemd, R., 2008. Late Archaean high-grade metamorphism in the Central Zone of the Limpopo Belt (South Africa): Petrological and geochronological evidence from the Bulai Pluton. Lithos 103, 333-351.

Moore, J.M., Tsikos, H., Polteau, S., 2001. Deconstructing the Transvaal Supergroup, South Africa: implications for Palaeoproterozoic palaeoclimate models. Journal of African Earth Sciences 33, 437-444.

Nelson, D.R., Trendall, A.F., Altermann, W., 1999. Chronological correlations between the Pilbara and Kaapvaal cratons. Precambrian Research 97, 165-189.

Ohmoto, H., 1992. Biogeochemistry of sulfur and the mechanisms of sulfide-sulfate mineralization in Archean oceans. In: Schidlowski, M. (Ed.), Early Organic Evolution: Implications for Mineral and Energy Resources. Springer Verlag, Heidelberg, pp. 378397.

Ohmoto, H., 1996. Evidence in pre-2.2 Ga paleosols for the early evolution of atmospheric oxygen and terrestrial biota. Geology 24, 1135-1138.

Ohmoto, H., 1997. When did the Earth's atmosphere become oxic? The Geochemical News 93, 12-13 and 26-28.

Ohmoto, H., 1999. Redox state of the Archean atmosphere: evidence from detrital heavy minerals in ca. 3250-2750 Ma sandstones from the Pilbara Craton, Australia: Comment. Geology 27, 1150-1151.

Ohmoto, H., 2004. The Archaean atmosphere, hydrosphere and biosphere. In: Eriksson, P.G., Altermann, W., Nelson, D.R., Mueller, W.U., Catuneanu, O. (Eds.), The Precambrian Earth: tempos and events, Developments in Precambrian Geology 12. Elsevier, Amsterdam, pp. 361-388.

Olsson, J.R., Söderlund, U., Klausen, M.B., Ernst, R.E., 2010. U-Pb baddeleyite ages linking major Archean dyke swarms to volcanic-rift forming events in the Kaapvaal craton (South Africa), and a precise age for the Bushveld Complex. Precambrian Research 183(3), 490-500.

Perchuk, L.L., Van Reenen, D.D., Varlamov, D.A., van Kal, S.M., Tabatabaeimanesh, Boshoff, R., 2008. P-T record of two high-grade metamorphic events in the Central Zone of the Limpopo Complex, South Africa. Lithos 103, 70-105.

Pesonen, L.J., Elming, S.-A., Mertanen, S., Pisarevsky, S., D'Agrella-Filho, M.S., Meert, J.G., Schmidt, P.W., Abrahamsen, N., Bylund, G., 2003. Palaeomagnetic configuration of continents during the Proterozoica. Tectonophysics 375, 289-324.

Polteau, S., Moore, J.M., Tsikos, H., 2006. The geology and geochemistry of the Palaeoproterozoic Makganyene diamictite. Precambrian Research 148, 257-274. 
Potgieter, G.J., 1992. Tektonisme langs die noordoostelike rand van die Bosveldkompleks, Suid-Afrika. PhD thesis, University of Pretoria, South Africa, p. 214.

Rainbird, R.H., 1992. Anatomy of a large-scale braid-plain quartzarenite from the Neoproterozoic Shaler Group, Victoria Island, Northwest Territories, Canada. Canadian Journal of Earth Sciences 29, 2537-2550.

Rigby, M.J. 2009. Conflicting P-T paths within the Central Zone of the Limpopo Belt: a consequence of different thermobarometric methods? Journal of African Earth Sciences 54, 111-126.

Rigby, M.J., Mouri, H., Brandl, G., 2008. A review of the P-T-t evolution of the Limpopo Belt: constraints for a tectonic model. Journal of African Earth Sciences 50, 120-132.

Robb, L.J., Meyer, F.M., 1995. The Witwatersrand Basin, South Africa: geological framework and mineralization processes. Economic Geology Research Unit, Information Circular 293, University of Witwatersrand, Johannesburg, South Africa, p. 37.

Rye, R., Holland, H.D., 1998. Paleosols and the evolution of atmospheric oxygen: a critical review. American Journal of Science 298, 621-672.

Santosh, M., Maruyama, S., Yamamoto, S., 2009. The making and breaking of supercontinents: Some speculations based on superplumes, super downwelling and the role of tectosphere. Gondwana Research, 324-341.

Schmidt, P.W., Williams, G.E., 1999. Paleomagnetism of the Paleoproterozoic hematitic breccia and paleosol at Ville-Marie, Québec: further evidence for the low paleolatitude of Huronian glaciation. Earth and Planetary Science Letters 172, 273-285.

Simpson, E.L., Eriksson, K.A., Eriksson, P.G., Bumby, A.J., 2002. Eolian dune degradation and generation of massive sandstone bodies in the Paleoproterozoic Makgabeng Formation, Waterberg Group, South Africa. Journal of Sedimentary Research 72, 40-45.

Simpson, E.L., Alkmim, F.F., Bose, P.K., Bumby, A.J., Eriksson, K.A., Eriksson, P.G., Martins-Neto, M.A., Middleton, L.T., Rainbird, R.H., 2004. Sedimentary dynamics of Precambrian aeolianites. In: Eriksson, P.G., Altermann, W., Nelson, D.R., Mueller, W.U., Catuneanu, O. (Eds.), The Precambrian Earth: tempos and events. Elsevier, Amsterdam, pp. 642-657.

Söderlund, U., Hofmann, A., Klausen, M.B., Olsson, J.R., Ernst, R.E., Persson, P.-O., 2010. Towards a complete magmatic barcode for the Zimbabwe craton: Baddeleyite U$\mathrm{Pb}$ dating of regional dolerite dyke swarms and sill complexes. Precambrian Research 183(3), 388-398. 
Sohl, L. E., Christie-Blick, N., Kent, D. V., 1999. Paleomagnetic polarity reversals in Marinoan (ca. $600 \mathrm{Ma}$ ) glacial deposits of Australia: Implications for the duration of lowlatitude glaciation in Neoproterozoic time. Geological Society of America Bulletin 111, 1120-1139.

Stanistreet, I.G., 1993. Ancient and modern examples of tectonic escape basins: the Archaean Witwatersrand Basin compared with the Cenozoic Maracaibo Basin. In: Frostick, L.E., Steel, R.J. (Eds.), Tectonic Controls and Signatures in Sedimentary Successions. International Association of Sedimentologists Special Publication 20, Blackwell, Oxford, pp. 363-376.

Tinker, J., de Wit, M.J., Grotzinger, J., 2002. Seismic stratigraphic constraints on Neoarchean-Paleoproterozoic evolution of the western margin of the Kaapvaal craton, South Africa: South African Journal of Geology 105, 107-134.

Trendall, A.F., 2002. The significance of iron-formation in the Precambrian stratigraphic record. In: Altermann, W., Corcoran, P.L. (Eds.), Precambrian Sedimentary Environments: A Modern Approach to Ancient Depositional Systems. International Association of Sedimentologists Special Publication 33, Blackwell, Oxford, pp. 33-66.

Trendall, A.F., Compston, W., Williams, I.S., Armstrong, R.A., Arndt, N.T., McNaughton, N.J., Nelson, D.R., Barley, M.E., Beukes, N.J., De Laeter, J.R., Retief, E.A., Thorne, A.M., 1990. Chronological comparison of the volcano-sedimentary sequences of the Kaapvaal and Pilbara cratons between 3.2 and 2.4 Ga. Abstract, Third Archaean Symposium, Perth, Australia, p. 81-83.

Van der Neut, M., Eriksson, P.G., 1999. Palaeohydrological parameters of a Proterozoic braided fluvial system (Wilgerivier Formation, Waterberg Group, South Africa) compared with a Phanerozoic example. In: Smith, N.D., Rogers, J. (Eds.), Proceedings of the $6^{\text {th }}$ International Fluvial Conference. International Association of Sedimentologists Special Publication 28, Blackwell, Oxford, pp. 381-392.

Van der Westhuizen, W.A., de Bruiyn, H., Meintjies, P.G., 1991. The Ventersdorp Supergroup: an overview. Journal of African Earth Sciences 13, 83-105.

Van Reenen, D.D., Perchuk, L.L., Smit, CA.A. et al., 2004. Structural and P-T evolution of a major cross fold in the Central Zone of the Limpopo high-grade terrain, South Africa. Journal of Petrology, 45, 1413-1439

Van Reenen, D.D., Boshoff, R., Smit, CA.A., Perchuk, L.L., Kramers, J.D., McCourt, S., Armstrong, R.A., 2008. Geochronological problems related to polymetamorphism in the Limpopo Complex, South Africa. Gondwana Research 14, 644-662.

Visser, J.N.J., 1971. The deposition of the Griquatown Glacial Member in the Transvaal Supergroup. Transactions of the Geological Society of South Africa 74, 187-199. 
Visser, J.N.J., 1999. Lithostratigraphy of the Makganyene Formation (Postmasburg Group). South African Committee for Stratigraphy, Lithostratigraphic Series 34, 1-7.

Voegelin, A.R., Nägler, T.F., Beukes, N.J. Lacassie, J.P., 2010. Molybdenum isotopes in late Archean carbonate rocks: Implications for early Earth oxygenation. Precambrian Research 182, 70-82.

Vos, R.G., Eriksson, K.A., 1977. An embayment model for tidal and wave-swash deposits occurring within a fluvial dominated Proterozoic sequence in South Africa. Sedimentary Geol. 18, 161-173.

Walker, J.CA.G., 1977. Evolution of the Atmosphere. Macmillian, New York, p. 318.

Walker, J.CA.G., Klein, CA., Sachidlowski, M., Schopf, J.W., Stevenson, D.J., Walter, M.R., 1983. Environmental evolution of the Archean-Early Proterozoic Earth. In: Schopf, J.W. (Ed.), Earth's Earliest Biosphere - its Origin and Evolution. Princeton University Press, Princeton, New Jersey, pp. 260-290.

Walraven, F., Hattingh, E., 1993. Geochronology of the Nebo granite, Bushveld Complex. South African Journal of Geology 96, 31-41.

Walraven, F., Martini, J., 1995. Zircon Pb-evaporation age determinations of the Oak Tree Formation, Chuniespoort Group, Transvaal Sequence: implications for TransvaalGriqualand West basin correlations. South African Journal of Geology 98, 58-67.

Williams, G.E., 2004a. The paradox of Proterozoic glaciomarine deposition, open seas and strong seasonality near the Palaeo-Equator: global implications. In: Eriksson, P.G., Altermann, W., Nelson, D.R., Mueller, W.U., Catuneanu, O. (Eds.), The Precambrian Earth: tempos and events. Elsevier, Amsterdam, pp. 448-459.

Williams, G.E., 2004b. Earth's Precambrian rotation and the evolving lunar orbit: implications of tidal rhythmite data for palaeogeophysics. In: Eriksson, P.G., Altermann, W., Nelson, D.R., Mueller, W.U., Catuneanu, O. (Eds.), The Precambrian Earth: tempos and events. Elsevier, Amsterdam, pp. 473-482.

Williams, G. E., Schmidt, P. W., 1997. Paleomagnetism of the paleoproterozoic Gowganda and Lorrain Formations, Ontario: low paleolatitude for Huronian glaciation. Earth and Planetary Science Letters 153, 157-169.

Williams, H., Hoffman, P.F., Lewry, J.F., Monger, J.W.H., Rivers, T., 1991. Anatomy of North America: thematic portrayals of the continent. Tectonophysics 187, 117-134.

Wingate, M.T.D., 1998. A palaeomagnetic test of the Kaapvaal-Pilbara (Vaalbara) connection at $2.78 \mathrm{Ga}$. South African Journal of Geology 101, 257-274. 
Wright, D.T., Altermann, W., 2000. Microfacies development in Late Archaean stromatolites and oolites of the Ghaap Group of South Africa. Geological Society London Special Publications 178, 51-70.

Wright, D.T., Oren, A., 2005. Nonphotosynthetic bacteria and the formation of carbonates and evaporates through time. Geomicrobiology Journal 22(1-2), 27-53.

Young, G.M., 2004. Earth's two great Precambrian glaciations: aftermath of the "Snowball Earth" hypothesis. In: Eriksson, P.G., Altermann, W., Nelson, D.R., Mueller, W.U., Catuneanu, O. (Eds.), The Precambrian Earth: tempos and events. Elsevier, Amsterdam, pp. 440-448.

Zeh, A., Klemd, R., Buhlmann, S., Barton, J.M., 2004. Pro- and retrograde P-T evolution of granulites of the Beit Bridge Complex (Limpopo Belt, South Africa): Constraints from Quantitative phase diagrams and geotectonic implications. Journal of Metamorphic Geology 22, 79-95.

Zeh, A., Gerdes, A., Klemd, R., Barton Jr., J.M., 2007. Archaean to Proterozoic crustal evolution in the central zone of the Limpopo Belt (South Africa-Botswana): Constraints from combined $\mathrm{U}-\mathrm{Pb}$ and $\mathrm{Lu}-\mathrm{Hf}$ isotope analyses of zircon. Journal of Petrology 48, 1605-1639.

Zeh, A., Gerdes, A., Barton, J.M., Jr., 2009. Archean accretion and crustal evolution of the Kalahari Craton - the zircon age and Hf isotope record of granitic rocks from Barberton/Swaziland to the Francistown Arca. Journal of Petrology 50(5), 933-966.

Zhong, S., Zhang, N., Li, Z.-X., Roberts. J.H., 2007. Supercontinent cycles, true polar wander, and very long-wave length mantle convection. Earth and Planetary Science Letters 261, 551-564. 


\section{Figure captions}

Fig. 1. Schematic summary of Earth evolution from ca. $4.4-1.6 \mathrm{Ga}$, emphasizing major inferred changes and events and their possible impact on the sedimentary record (modified after Eriksson et al., 2007). "Superevents" identified at ca. $2.7 \mathrm{Ga}$ and from ca. 2.2-1.8 Ga refer to combinations of major global events (cf., Eriksson et al., 2004).

Figure 2. (a) Sketch map of the Kaapvaal craton, showing southeastern nucleus (made up of Barberton-South [BS] and -North [BN] terranes), accreted Murchison-North Kaapvaal (MNK) terrane, major Archean greenstone belts and the Witwatersrand-Pongola, Ventersdorp and Transvaal basins. The Colesberg magnetic lineament is inferred to be the suture of the assembled B-S, B-N, MNK terranes with the Kimberley (=westerly accreted terrane) cratonic block. The Central Zone (LCZ terrane) of the Limpopo mobile belt subsequently accreted to the north of the assembled Kaapvaal craton. (Modified after de Wit et al. 1992; Cheney, 1996; Tinker et al. 2002; Zeh et al. 2009).

Fig. 3. Sketch map (at top) and schematic profile through inferred Witwatersrand foreland basin system (below). The cross-sectional profile 2-2' on the map is shown below in the profile. Note that the preserved Witwatersrand basin equates to the foredeep depozone, with area "B" being an area of subsequent erosion of these foredeep strata. The two solid line half-circles, centred on the areas of maximum loading (numbered " 1 " and " 2 " for accreting northern and western composite terranes, respectively), outline the approximate distribution of the foredeep depozone; the forebulge developed outside the area covered by these two half-circles, with its apex (point "A"; see also profile, below) enclosed by the $-130 \mathrm{mgal}$ isoline of the gravity field. The three dashed circles suggest contour lines of the foreland system centred around the forebulge apex, A, with the outermost circle marking the position of the back-bulge axis (which equates with the depo-axis of the Pongola Supergroup basin), as also suggested in theoretical flexural profile models (cf. Catuneanu, 2001 and references therein). For the "greater Witwatersrand basin", the forebulge remained emergent, thereby separating discrete foredeep (fill = Witwatersrand Supergroup) and back-bulge (fill = Pongola Supergroup) sub-basins. Modified after Catuneanu (2001).

Figure 4. (a) Schematic geodynamic history chart proposed for the "greater Witwatersrand basin" (=Witwatersrand and correlated Pongola Supergroups), showing chronology, stratigraphy and major granitic events affecting this basin and its hinterland, as well as major terrane accretion and amalgamation events affecting the Kaapvaal craton, and flexural retroarc foreland basin system stages for the greater Witwatersrand depository. (b) Geodynamic history chart for the Ventersdorp basin. Minimum age of ca. 2.66 Ga for the upper part of the Ventersdorp Supergroup (Olsson et al., 2010) remains speculative.

Fig. 5. Schematic geodynamic history chart for the Transvaal Supergroup, in the Transvaal basin, showing lithostratigraphy, chronology, inferred tectonic settings and depositional paleoenvironments, as well as interpreted sequence stratigraphy (modified after Catuneanu and Eriksson 1999). Age near base of Pretoria Group (lower Timeball 
Hill Formation) from Hannah et al. (2004); remaining age data taken from references in Eriksson et al. (2001).

Fig. 6. (a) Sketch map of three Transvaal (Supergroup) sub-basins: Transvaal itself and Griqualand West (separated by the Vryburg rise, a palaeohigh), with the Kanye basin to the north of the palaeohigh.

Fig. 7. Profile through the upper ca. $50 \mathrm{~m}$ of the Timeball Hill Formation (Pretoria Group) showing a ca. $35 \mathrm{~m}$ thick diamictite succeeded by locally varved mudrocks and a thin chert conglomerate bed. Field profile measured by first author in Magaliesberg village.

Fig. 8. Lithostratigraphy of the Chuniespoort-Ghaap Groups, in the Transvaal and Griqualand West sub-basins of the Transvaal Supergroup, showing inferred correlations, age data and interpreted regressive-transgressive trends. The two left-hand columns are for the Prieska and Ghaap Plateau divisions of the Griqualand West sub-basin. Note that vertical scale reflects time and not thickness. Note also contact relationships with succeeding units of the Duitschland Formation, Pretoria and Postmasburg Groups. Modified after Eriksson et al., 2006.

Fig. 9. Vertical profile through the Duitschland Formation on the farm Duitschland, simplified from original in Frauenstein et al. (2009).

Figure 10. Typical profile through the Makganyene Formation, Griqualand West subbasin; profile from Visser (1971), measured on farm Bolham Ku. Q 825, situated about $45 \mathrm{~km}$ south of Kuruman.

Figure 11. Sketch map showing the location of the Waterberg Group in South Africa: larger Main basin in the NE and smaller Middelburg basin east of Pretoria. Note that the Main Basin is bounded by Melinda (Palala) fault zone and Thabazimbi-Murchison lineament (TML), whereas the Middelburg basin is bounded by Kanye axis. 


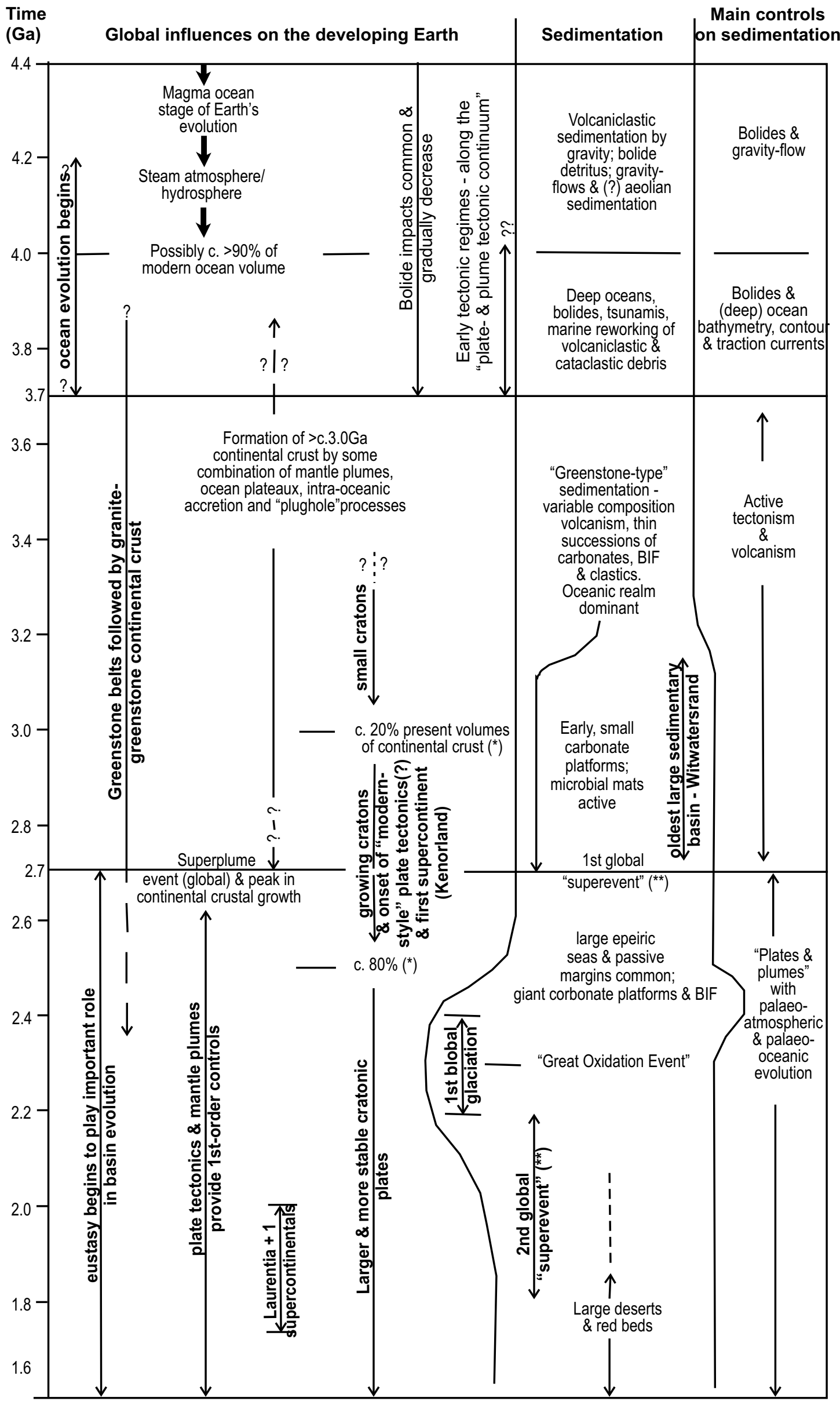

Fig. 1 


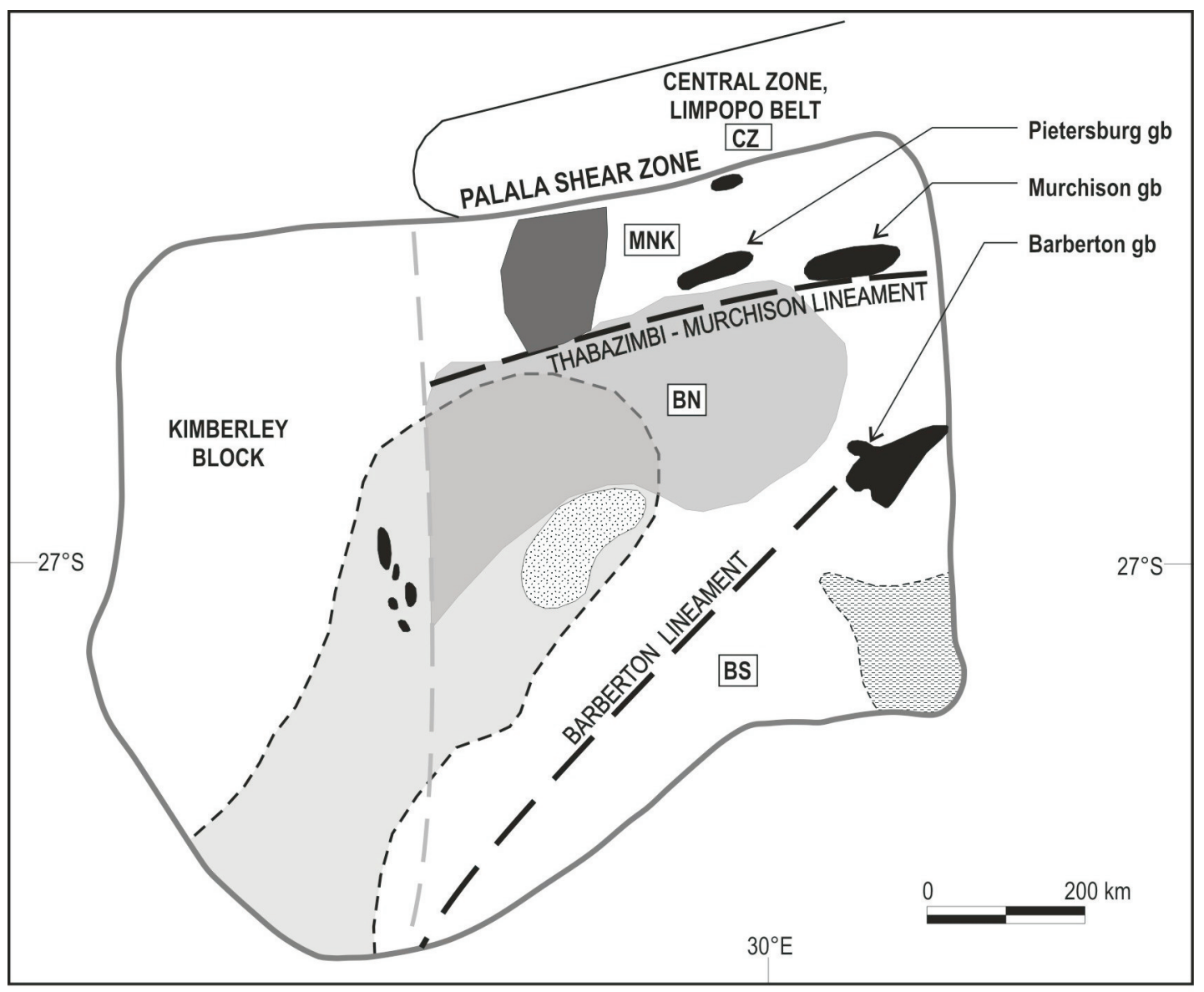

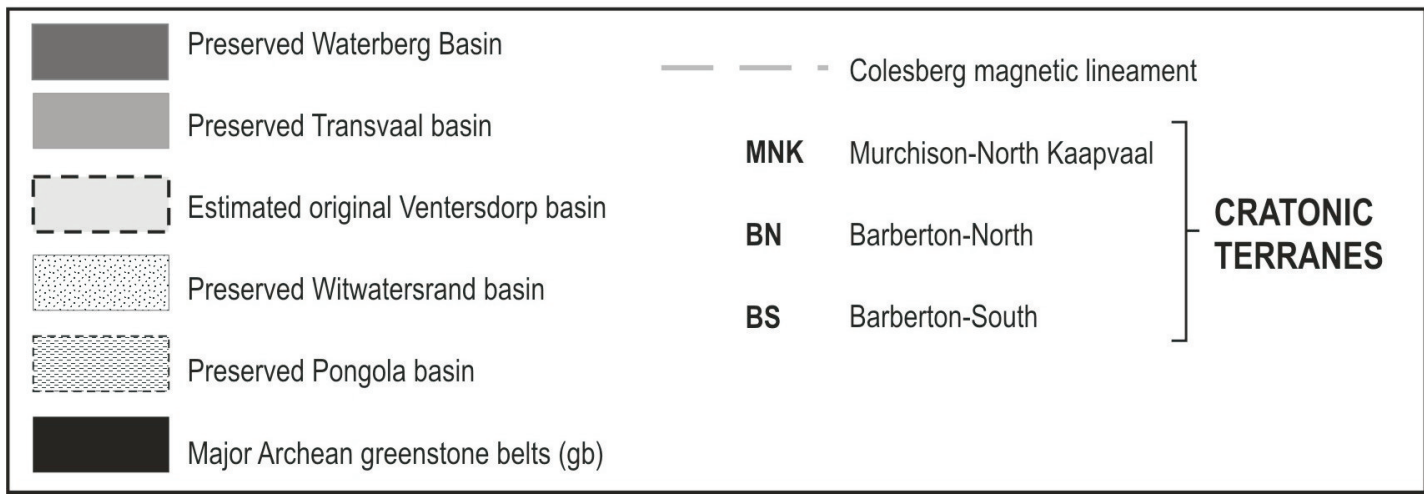

Fig. 2 


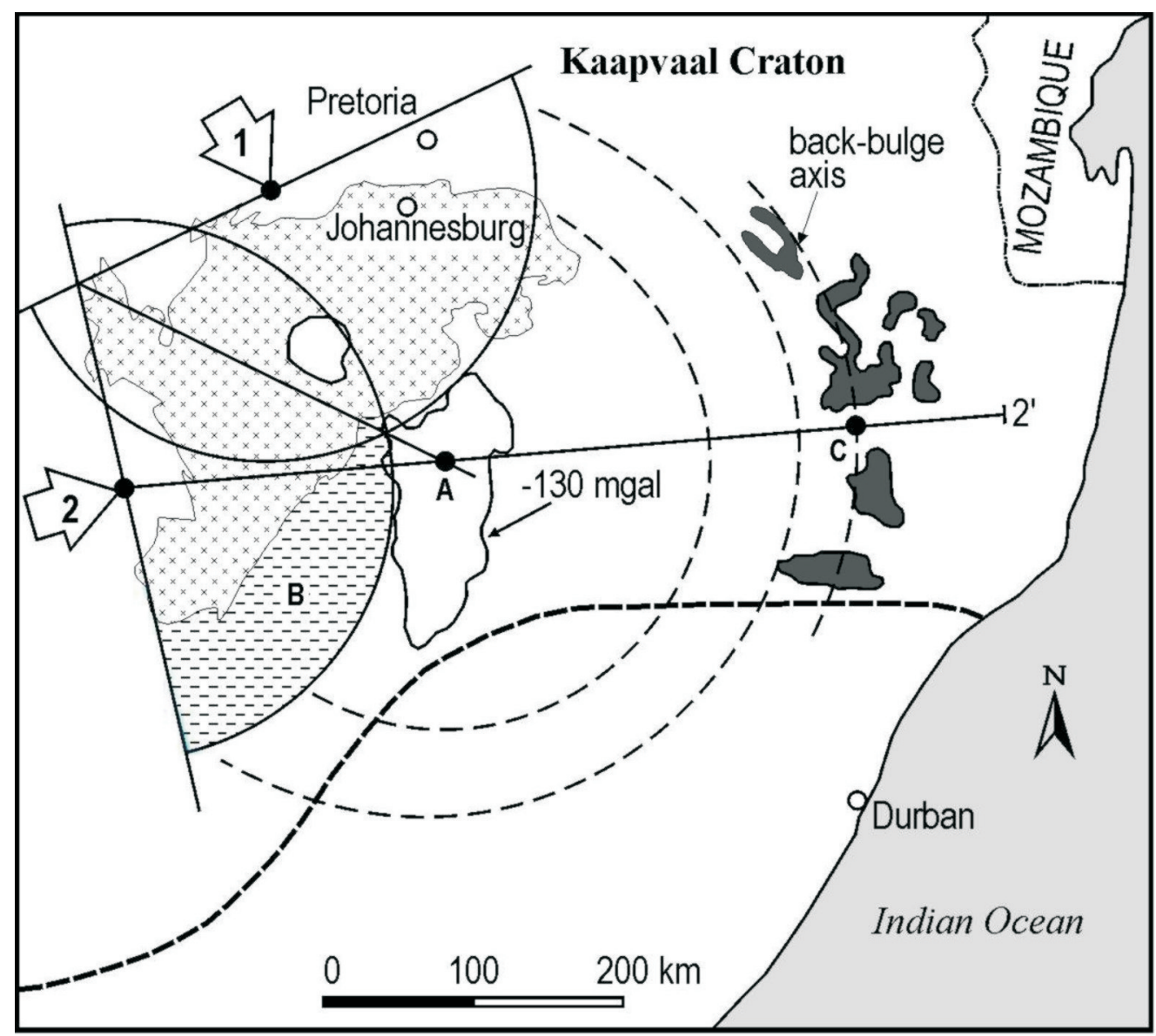

Witwatersrand (foredeep) strata $\quad---$ Kaapvaal
$\square$ Pongola strata

Area of post-Witwatersrand erosion of foredeep strata

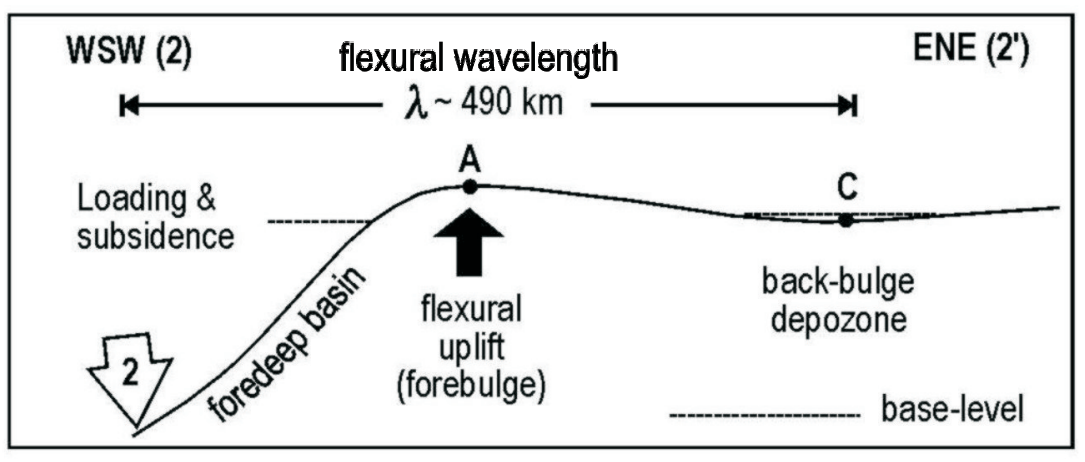

Fig. 3 


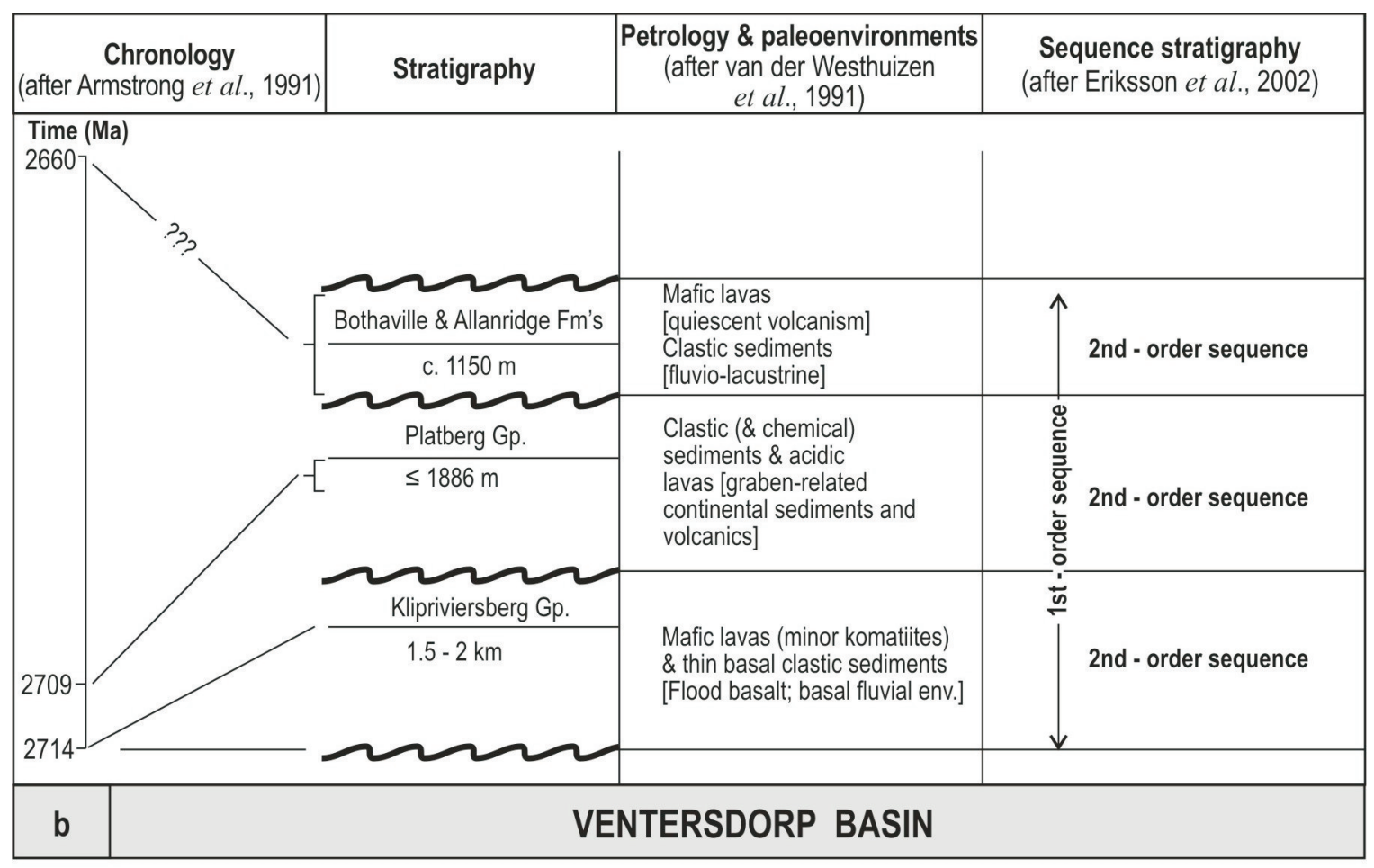

\begin{tabular}{|c|c|c|c|c}
\hline $\begin{array}{c}\text { Chronology } \\
\text { (after Robb } \\
\begin{array}{c}\text { Meyer, 1995 \& } \\
\text { references therein) }\end{array}\end{array}$ & Stratigraphy & $\begin{array}{c}\text { Granitic } \\
\text { events } \\
\text { (after Robb \& } \\
\text { Meyer, 1995) }\end{array}$ & $\begin{array}{c}\text { Assembly of } \\
\text { Kaapvaal craton } \\
\text { (after De Wit } \\
\text { et al. (1992) \& } \\
\text { Tinker et al. (2002)) }\end{array}$ & $\begin{array}{c}\text { Flexural retro- } \\
\text { arc foreland basin } \\
\text { dynamics } \\
\text { (after Catuneanu, 2004) }\end{array}$ \\
\hline
\end{tabular}

Time (Ma)

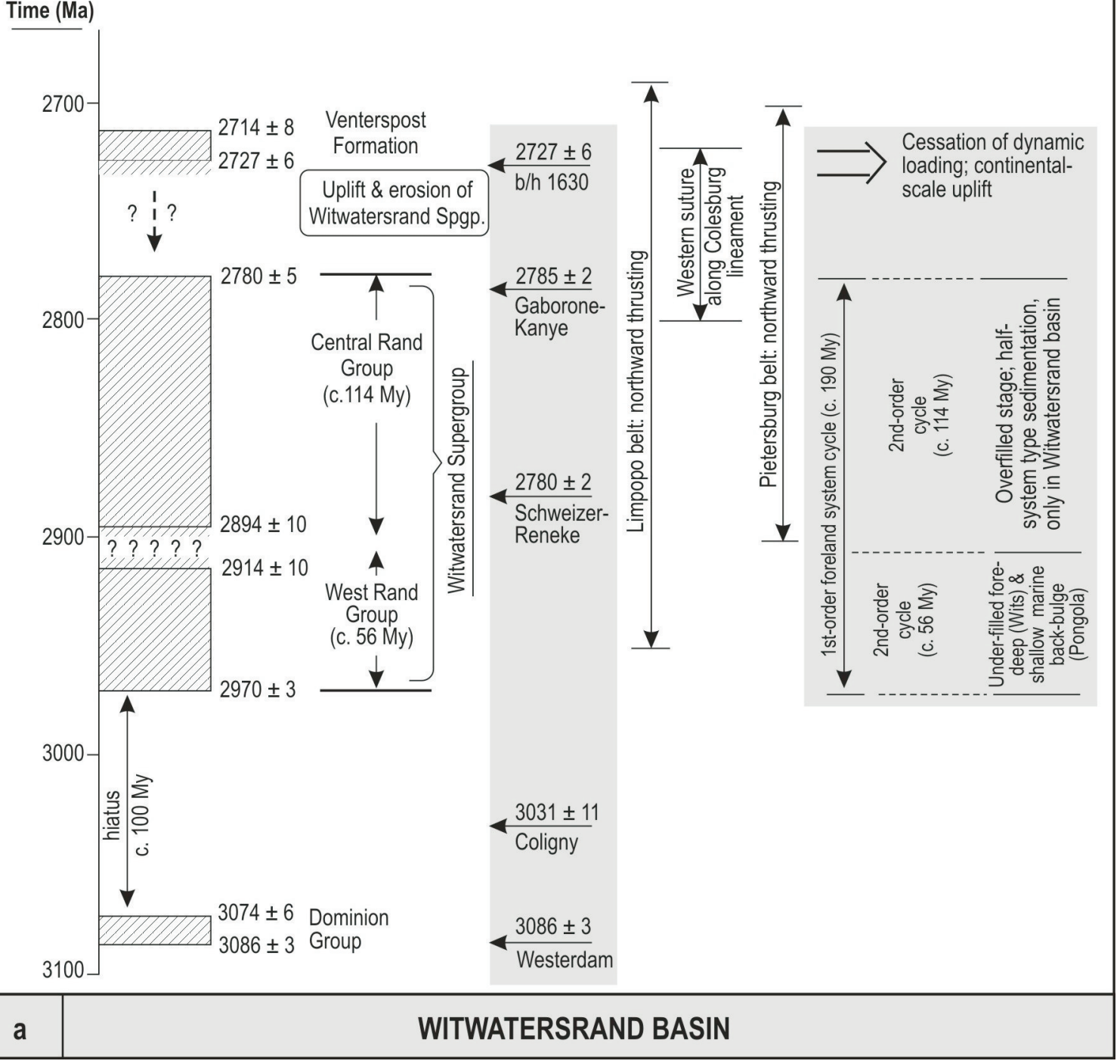

Fig. 4 


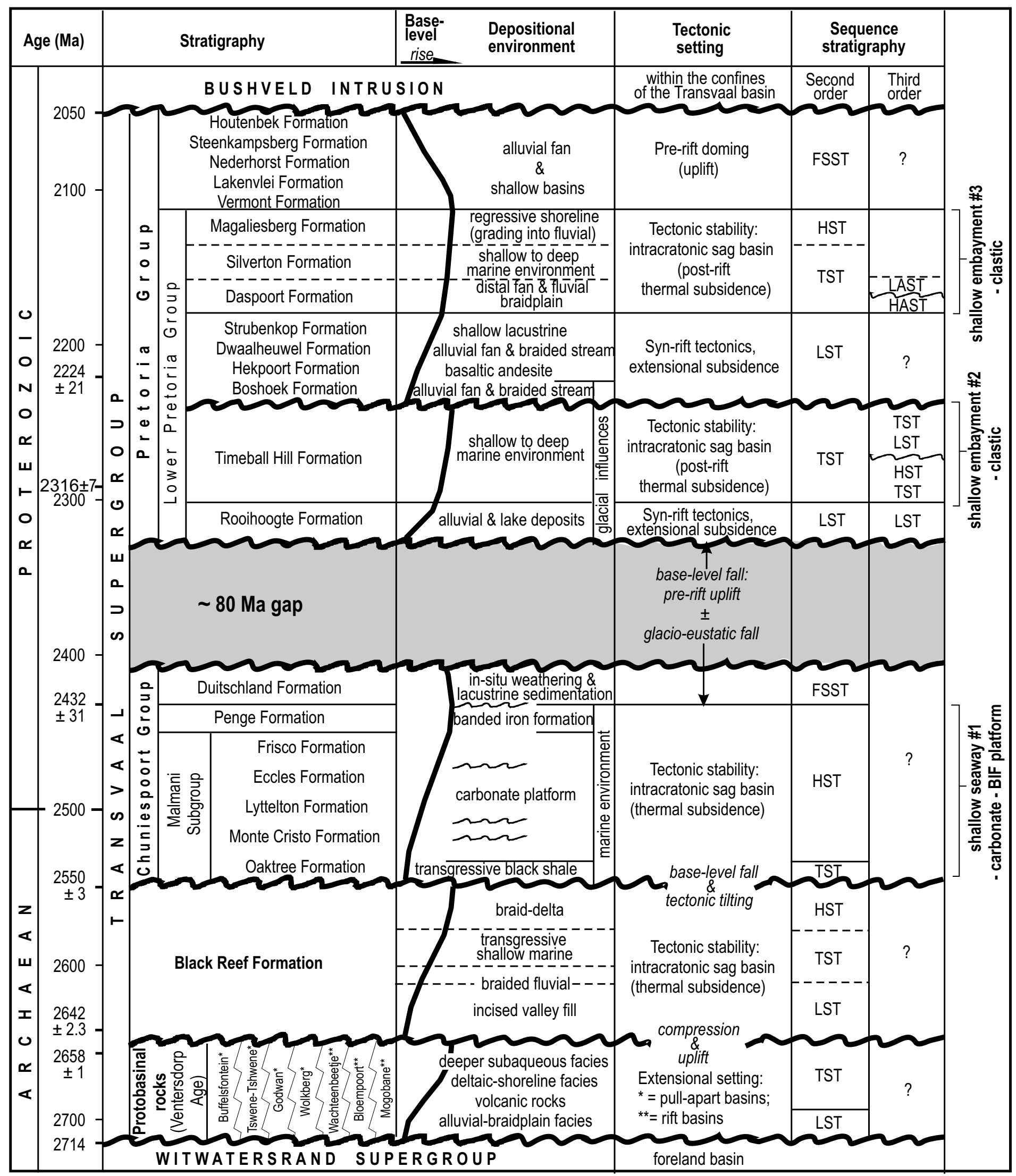

Fig. 5 


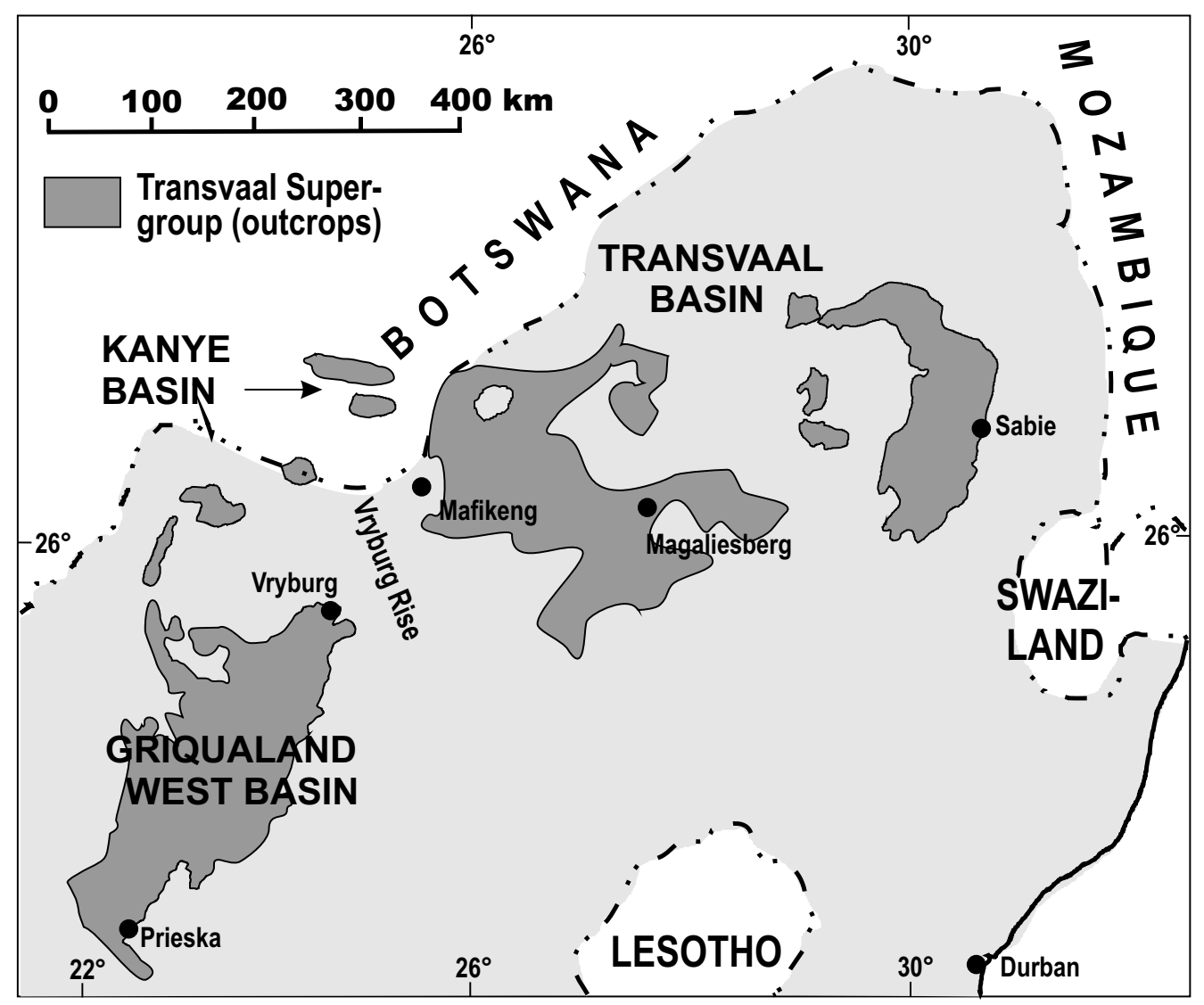

Fig. 6 


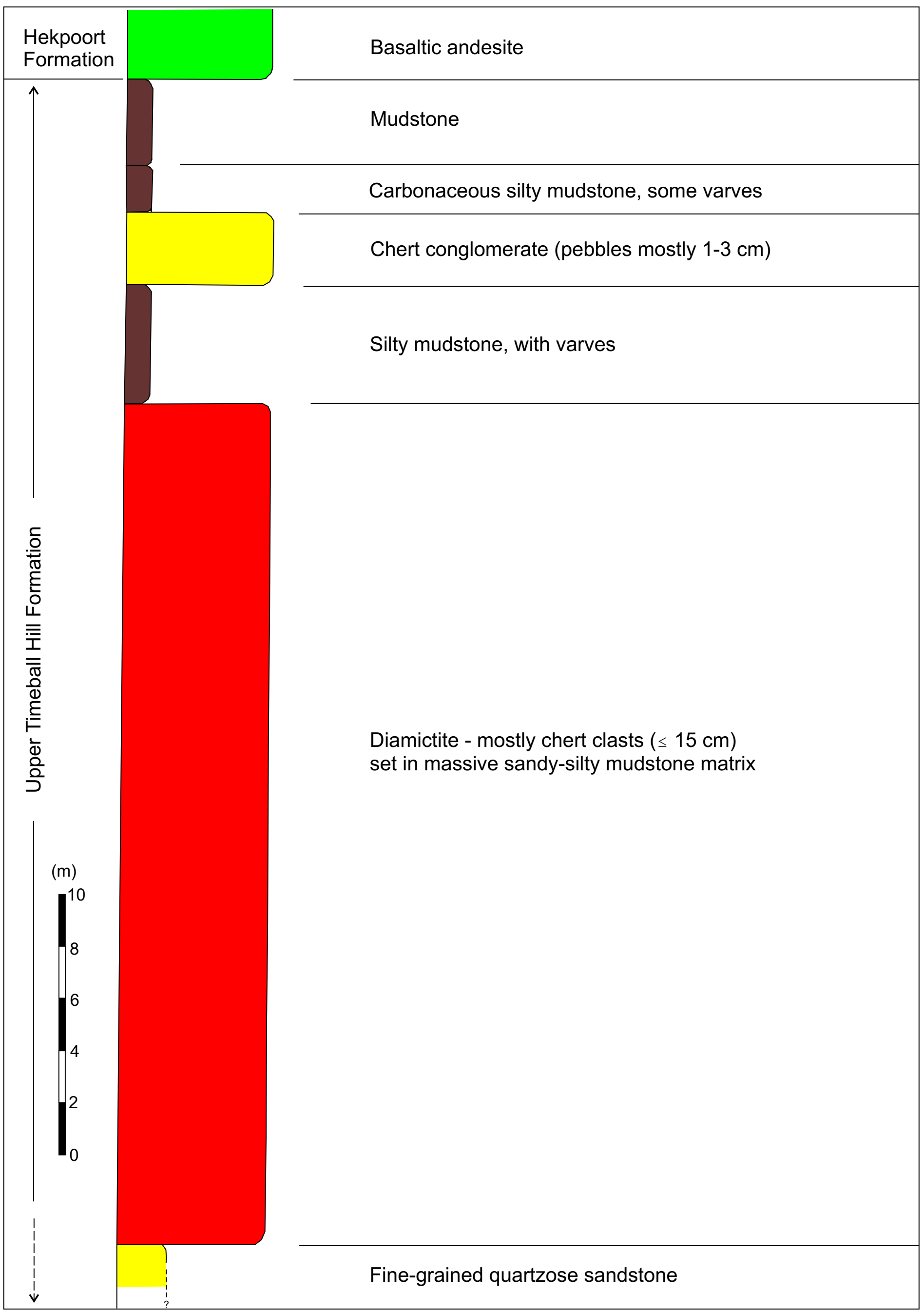

Fig. 7 


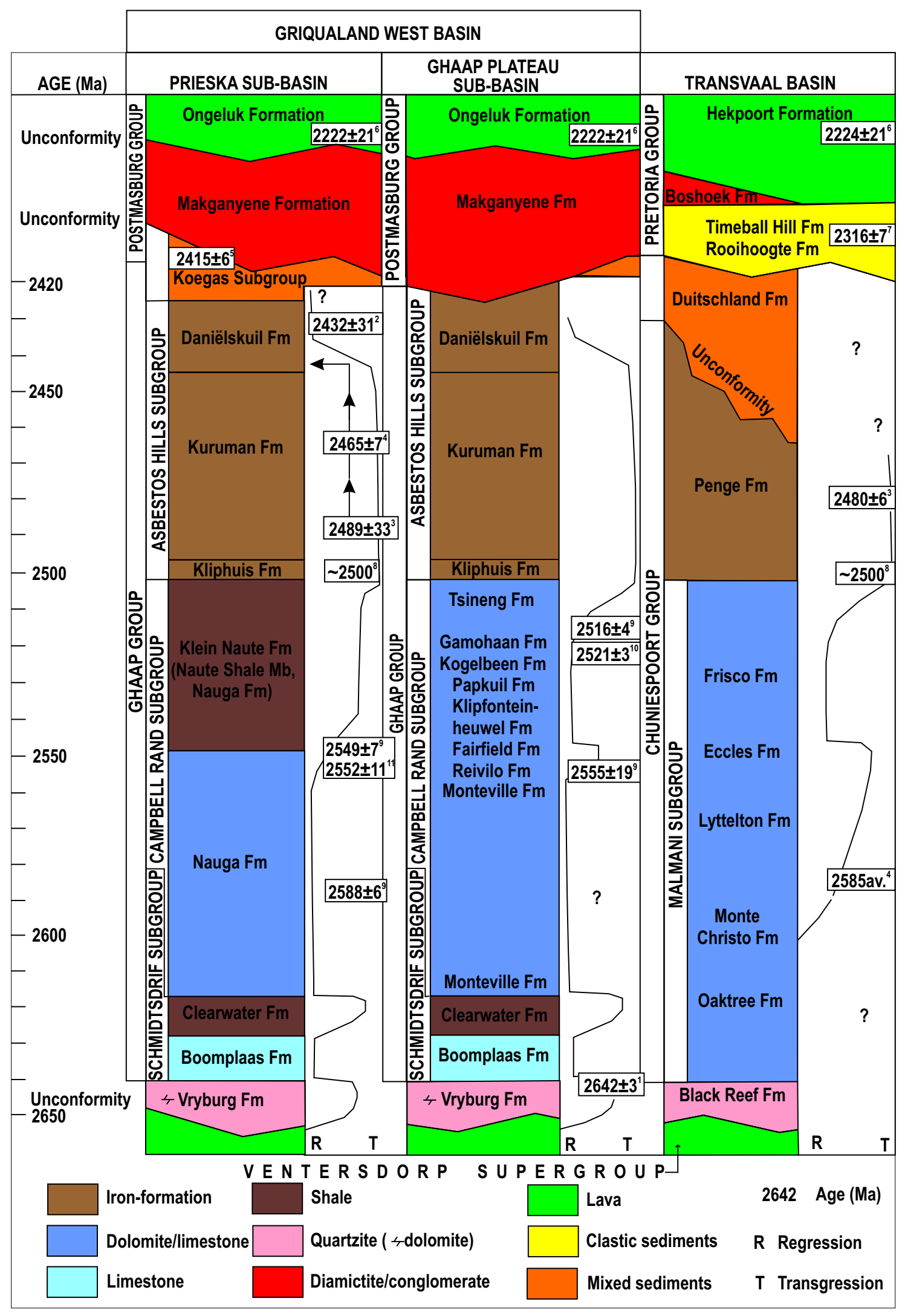

Fig. 8 

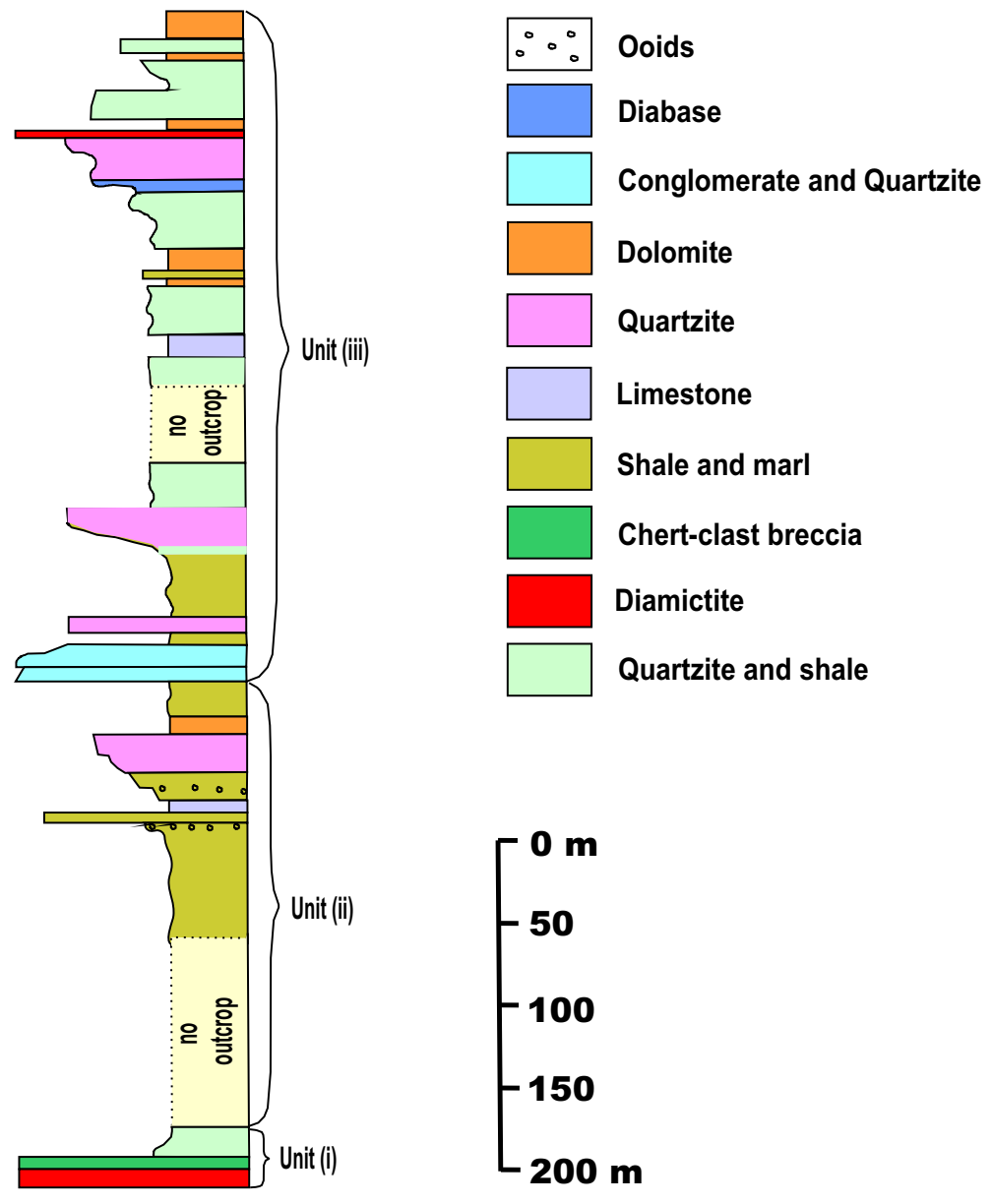

Fig. 9 


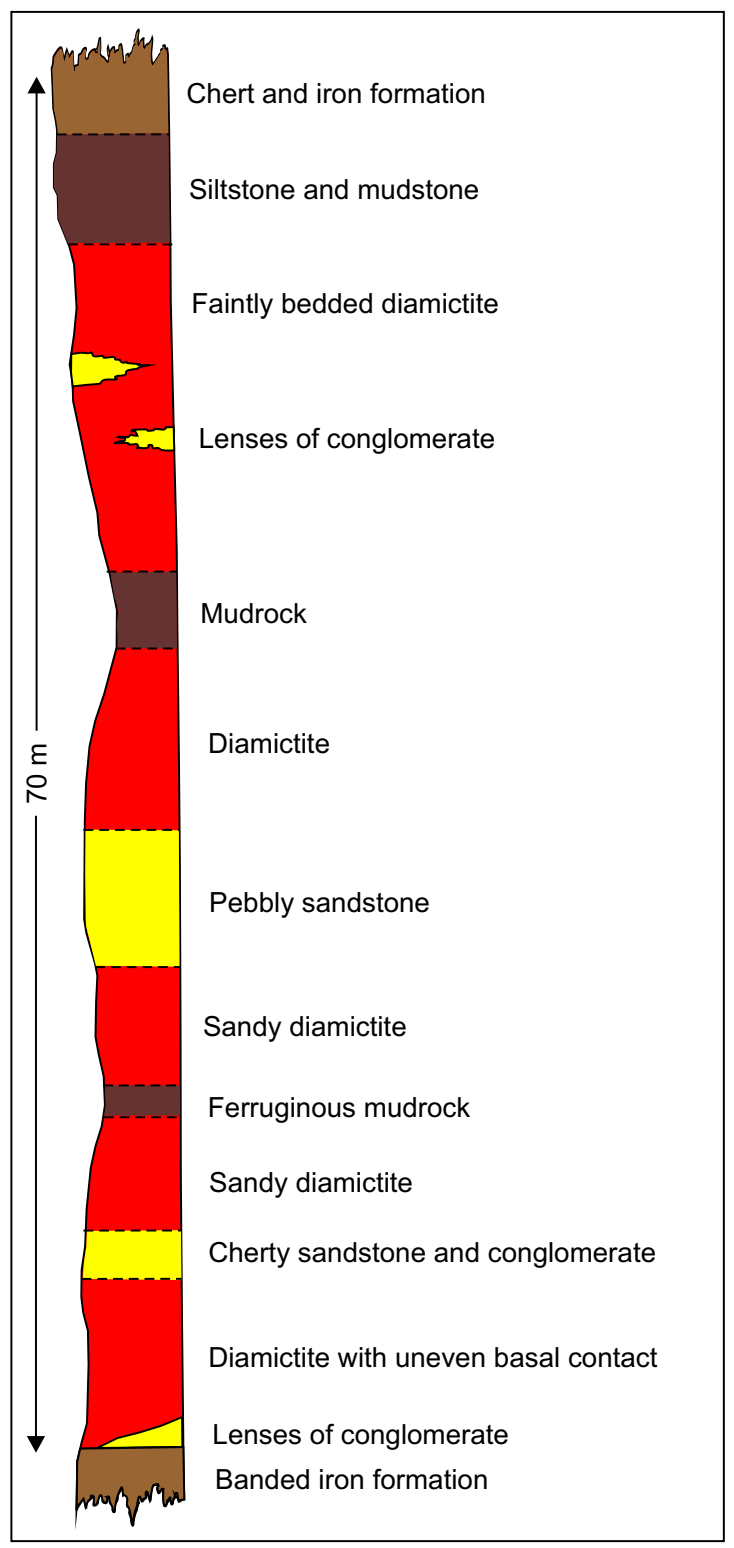

Fig. 10 


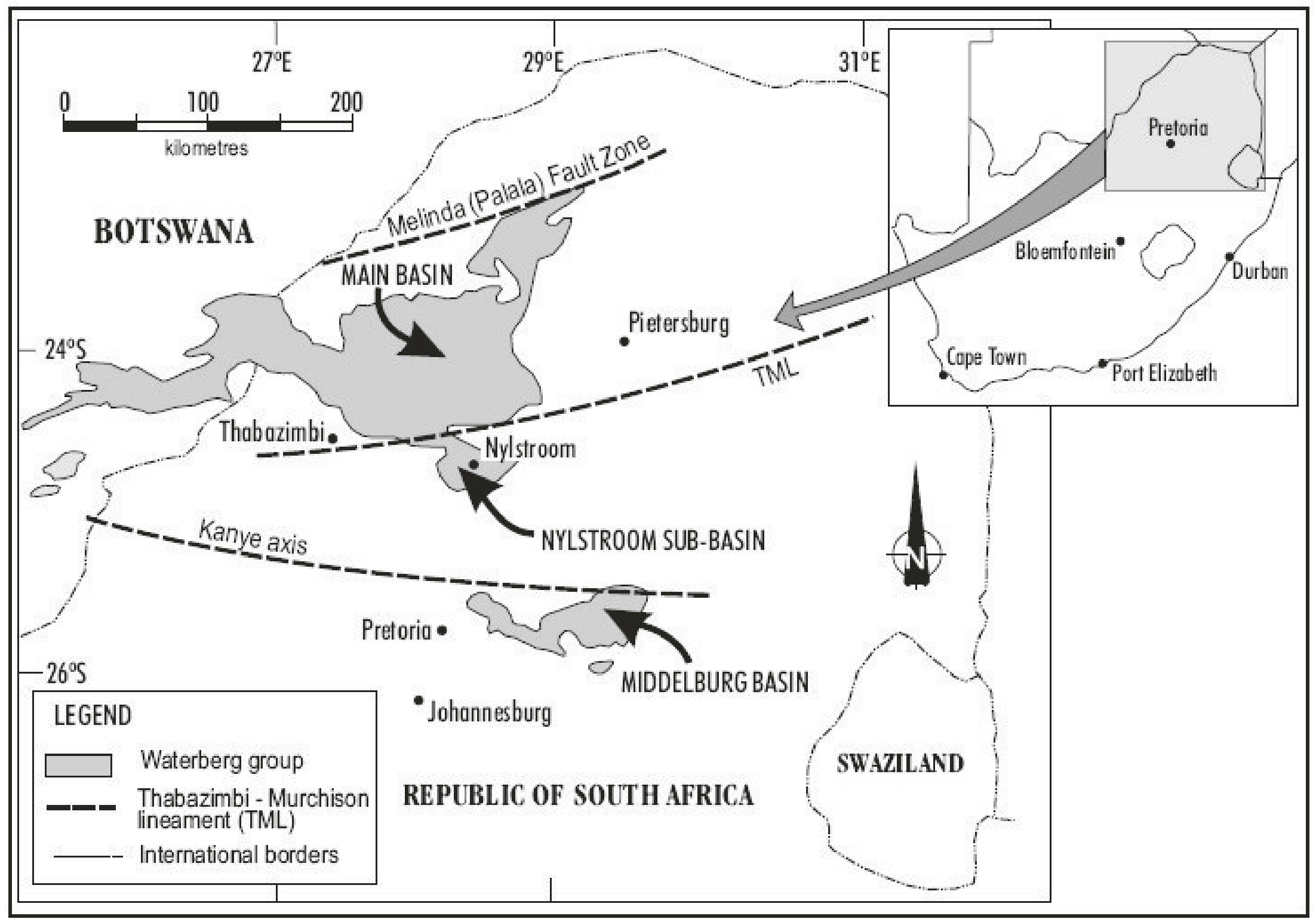

Fig. 11 